\title{
Psychological Drivers of Alternative Fuel Vehicles' Adoption and Ecologically Responsible Use
}

\author{
Muhammad Abid Saleem ${ }^{D},{ }^{1}$ Rao Akmal Ali, ${ }^{2}$ Syed Noman Ali Shah ${ }^{D},{ }^{3}$ Sadaf Zahra $\left(\mathbb{D},{ }^{4}\right.$ \\ Muhammad Haroon Hafeez, ${ }^{5}$ and Ninh Nguyen (iD) ${ }^{1}$ \\ ${ }^{1}$ Asia Pacific College of Business and Law, Charles Darwin University, Darwin, Australia \\ ${ }^{2}$ Department of Management Sciences, National University of Modern Languages (NUML), Islamabad, \\ Multan Campus, Pakistan \\ ${ }^{3}$ National University of Modern Languages (NUML), Islamabad, Multan Campus, Pakistan \\ ${ }^{4}$ College of Business, Law and Governance, James Cook University (JCU), Townsville, Australia \\ ${ }^{5}$ Institute of Management Sciences, Bahauddin Zakariya University, Multan, Pakistan
}

Correspondence should be addressed to Muhammad Abid Saleem; muhammad.saleem@cdu.edu.au

Received 27 July 2021; Revised 30 November 2021; Accepted 16 December 2021; Published 29 December 2021

Academic Editor: Stefano de Luca

Copyright (C) 2021 Muhammad Abid Saleem et al. This is an open access article distributed under the Creative Commons Attribution License, which permits unrestricted use, distribution, and reproduction in any medium, provided the original work is properly cited.

\begin{abstract}
Environmental problems caused by global warming are becoming alarming with every passing day. To curb greenhouse gas (GhG) emissions, promoting alternative fuel vehicles (AFVs) and sustainable transport mode choices is critical. This study explores the predictors of eco-social purchase, use, and conservation intentions in a developing country by employing an extended model of the theory of planned behaviour (TPB). Using a self-administered survey technique, data were collected from a nationally representative sample of 1372 customers of three leading automobile manufacturers from eight big cities of Pakistan. Partial Least Squares Structural Equation Modelling (PLS-SEM) was applied to test the measurement and structural models. Results showed that the extended model of TPB received support in the context of Pakistani culture and for the targeted behaviours related to ecosocial purchase, use, and conservation intentions concerning AFVs. Implications for marketers and theoretical contribution are discussed at the end.
\end{abstract}

\section{Introduction}

Exponential growth in environmental problems, including climate change, global warming, air and water pollution, and biodiversity loss, are attributed mainly to human activities, including irresponsible production and consumption $[1,2]$. One major human-induced environmental problem is greenhouse gas (GhG) emissions generated by industrial production, household heating and cooling systems, and transportation activity [3]. With a transition in economies of high-growth developing nations, the transportation sector's contribution towards GhG emissions is expected to grow even more significant. Therefore, it is imperative to institute a research-informed policy to foster sustainable behaviours, particularly those targeted towards choice and use of lowcarbon, cleaner, and more sustainable transport options.
With evidence suggesting that a large number of consumers are aware of and willing to support environmentally friendly products in the developing countries [4], many travel/mobility-related policies have been instituted to encourage the choice of low-carbon travel modes and alternative fuel vehicles (AFVs) [5-7]. With some signs of success in shifting behaviours towards a sustainable lifestyle and eco-brand choices in the developed countries, there remains a huge void as to what drives consumers to have sustainable choices in the developing countries. Particularly concerning AFVs, consumers appear to be highly reluctant given the lack of infrastructure support, high product prices, performance scepticism, and limited choices available [8-10]. A plethora of research has focussed on exploring the impact of both structural measures $[7,11,12]$ and psychological factors $[6,9,10,13]$ driving consumer preference for 
adopting low-carbon AFVs. Almost unequivocally, the extant research concludes that volunteering behaviour can be more instrumental in harnessing the benefits of cleaner automotive technology than structural measures to protect the environment through reduced emissions. Nevertheless, behavioural support for the choice of AFVs and ecologically responsible use of personal cars has not remained the focus of research in the developing countries, given the nascent stage of AFVs life cycle in such countries. Therefore, this current study focuses on a developing country context to understand what drives ecologically conscious consumer behaviour relevant to the choice and use of AFVs.

Studies conducted on behavioural determinants leading to the choice of AFVs in developed countries suggest that demographic, situational, contextual, and psychological factors are key drivers of such behaviours [14]. However, psychological factors are more stable than the other three types. To this end, studies have mainly focussed on volitional (theory of planned behaviour (TPB)) and normative conduct theories (ValueBelief-Norms (VBN)) to explain behaviours relevant to sustainability, environmental support, social support, choice of energy-efficient products, willingness to pay for eco-brands, and organic food (for instance, see [3, 15-19]). While a general consensus is found among researchers regarding the efficacy of the aforementioned social-psychological approaches to studying eco-socially conscious consumer behaviours, some voices of dissent cannot be ignored. For instance, Sniehotta, Presseau, and Araújo-Soares [20], in their critical commentary on the value of the TPB, argued that the theory is weak in explaining the targeted behaviour, has low predictive power in specific contexts, and is over parsimonious with only four constructs explaining volitional behaviours. Since then, researchers have suggested that contextual extension of the TPB is inevitable to improve its explanatory power and prediction capability [21, 22]. Many studies since then have used an extended version of TPB by incorporating more constructs by either merging postulates of relevant theories or adding context-specific concepts in the causal chain model of TPB [23-25]. Taking the same approach, this current study presents an integrated TPB and VBN to determine eco-socially conscious consumer behaviour related to the choice and use of AFVs in a developing country context. To fully understand the impact and nature of relationships TPB and VBN constructs might have with eco-socially conscious consumer behaviour related to choice and use of AFVs, this study has identified three constructs (endogenous) that are related in nature but distinct in measurement (the further sections of this study elaborate more on this). Mainly, this study includes investigating consumer behavioural intentions towards the purchase and use of AFVs by (1) integrating psychological factors as determinants from TPB and VBN and (2) adding the contextual factor of Islamic religiosity in the integrated model of TPB and VBN.

\section{Theory and Hypotheses}

Derived from the Theory of Reasoned Action (TRA) [26], the TPB proposes that the behavioural intentions of a person follow a rational process of deliberate assessment and that behavioural intentions are an immediate proxy of actual behaviour. According to the TPB, behavioural intentions are influenced by attitude, subjective norms, and perceived behavioural control [27], contingent on a corresponding belief set, i.e., behavioural beliefs, normative beliefs, and control beliefs.

Many studies can be traced in the literature utilising TPB to explain various pro-environmental behaviours, including the adoption of carbon-free transportation [28], public bike acceptance [29], water conservation [30, 31], PHEVs adoption [32], and recycling behaviour [33]. The extant research suggests that the TPB framework can be specified in the particular context of a targeted behaviour and extended with the help of frameworks having identical causal chain processes [25]. Given the widespread application of the TPB model in predicting eco-socially conscious consumer behaviours and flexibility of extension, this study employs an extended TPB-VBN model to explain consumer choice and use of AFVs.

2.1. Relationship of Beliefs with Norms, Perceived Behavioural Control, and Attitude towards Behaviour. Beliefs are defined as "the subjective probability that an object (target behaviour) has a certain attribute (outcome of behaviour)" ([34], p. 96). In the TPB proposal, three sets of beliefs are proposed that link with their respective causal chain constructs: behavioural beliefs (associated with attitude towards behaviour), normative beliefs (associated with subjective norms), and control beliefs (associated with perceived behavioural control).

The expectancy-value model describes the interlink between behavioural beliefs and attitude towards behaviour [35], which argues that the degree of favourableness or unfavourableness towards a behaviour is the product of a latent disposition or tendency of individuals to respond towards that behaviour. In simple words, the likelihood of positive or negative attitudes towards specific behaviour depends on the type of evaluations about the consequences of performing the behaviour. "If behaviour is perceived to result in more positive than negative outcomes, the attitude towards behaviour would be favourable" ([34], p. 20). More specific to the context of this current study, if consumers believe that purchase and responsible use of AFVs may help to halt environmental degradation and emission reduction, they will likely have a positive attitude towards choice and responsible use of AFVs.

Quite similar to the assumption of how behavioural beliefs produce attitudes towards behaviour, the TPB proposal suggests that subjective norms are also derived from relevant normative beliefs. Normative beliefs refer to individuals' perceptions of what a particular referent or group expects of them (injunctive beliefs) or involved in (descriptive beliefs) in the context of a specific behaviour. Both injunctive and descriptive normative beliefs link, respectively, with injunctive (which refers to what a general referent or group expects one to do) and descriptive norms (which refers to what a general referent or group is actually involved in) [34, 36]. 
Finally, perceived behavioural control (PBC) is defined as "the extent to which people believe that they can perform a given behaviour and have control over its performance" ([34], pp. 154-155). Analogous to attitude towards behaviour and subjective norms, perceived behavioural control is also derived from salient control beliefs elicited by individuals. Therefore, it can be inferred that control beliefs are positively associated with perceived behavioural control [34]. In other words, consumers' beliefs about their ability to control environmental problems by purchasing and ethically using AFVs may lead to positive $\mathrm{PBC}$ perceptions.

The theoretical interlink of beliefs and respective attitudes, norms, and behavioural controls has been verified in several research studies [37-39]. Based on the theoretical explanation and the literature evidence, the following hypotheses are drawn:

H1: behavioural beliefs are positively associated with attitude towards eco-socially conscious consumer behaviour related to AFVs

$\mathrm{H} 2_{\mathrm{a}, \mathrm{b}}$ : normative injunctive $\left(\mathrm{H} 2_{\mathrm{a}}\right)$ and descriptive $\left(\mathrm{H} 2_{\mathrm{b}}\right)$ beliefs are positively associated with subjective injunctive and descriptive norms

H3: control beliefs are positively associated with perceived behavioural control

2.2. Subjective Norms, $P B C$, and Attitudes Leading to Behavioural Intentions. Fishbein and Ajzen [34] theorised that the motivation behind any behaviour (or behavioural intentions) is directly associated with the attitude towards behaviour, subjective norms, and perceived behavioural control. If an individual's assessment of a particular behaviour (attitude towards behaviour) is positive, likely, motivations towards that behaviour (behavioural intentions) would also be favourable and vice versa. Similarly, if there is social pressure (subjective norms) to perform specific behaviour, the probability of an individual's commitment to such behaviour will be high and vice versa. Based on Cialdini et al.'s [36] suggestions, this study evaluates subjective norms as descriptive subjective norms and injunctive subjective norms. Descriptive subjective norms are individuals' beliefs about how prevalent any behaviour is among their referent others, whereas the injunctive norms are the perceived pressure individuals feel to engage in a particular behaviour [40, 41].

Finally, Ajzen [27] added the concept of perceived behavioural control to the TRA and explained behavioural inexistence despite positive attitude and favourable subjective norms. It was highlighted that situational factors might hinder the elicitation of particular behaviour even if the attitudes towards behaviour and subjective norms favour it.

Subsequent research in the application of TPB, particularly related to pro-environmental behaviour, provided evidence on the conceptual relationship of constructs propounded in this theory. For example, in a study conducted in India, Arpita [42] reported that personal and socio-environmental norms, peer influence, and green self-identity positively affect attitudes towards behaviour and general pro-environmental behavioural intentions. Similarly, in another study, López-Mosquera, Lera-López, and Sánchez [43] highlighted that positive attitudes towards the environment lead to recycling behaviour, purchase, and sustainable use of environment-friendly cars. Identical findings were reported from the studies of Nimri et al. [44] and Moon [45], exploring green hotel accommodation and restaurant patronage behaviour, respectively.

Based on these studies and conceptual schema of TPB, the following hypotheses are proposed:

$\mathrm{H} 4_{\mathrm{a}, \mathrm{b}, \mathrm{c}}$ : subjective descriptive norms positively lead to eco-social purchase $\left(\mathrm{H} 4_{\mathrm{a}}\right)$, eco-social use $\left(\mathrm{H} 4_{\mathrm{b}}\right)$, and eco-social conservation $\left(\mathrm{H} 4_{c}\right)$ intentions related to AFVs

$\mathrm{H} 5_{\mathrm{a}, \mathrm{b}, \mathrm{c}}$ : subjective injunctive norms positively lead to eco-social purchase $\left(\mathrm{H} 5_{\mathrm{a}}\right)$, eco-social use $\left(\mathrm{H} 5_{\mathrm{b}}\right)$, and eco-social conservation $\left(\mathrm{H} 5_{\mathrm{c}}\right)$ intentions related to AFVs

$H 6_{a, b, c}:$ attitudes towards behaviour positively lead to eco-social purchase $\left(\mathrm{H}_{\mathrm{a}}\right)$, eco-social use $\left(\mathrm{H} 6_{\mathrm{b}}\right)$, and eco-social conservation $\left(\mathrm{Hb}_{\mathrm{c}}\right)$ intentions related to AFVs

$\mathrm{H} 7_{\mathrm{a}, \mathrm{b}, \mathrm{c}}$ : perceived behavioural control positively leads to eco-social purchase $\left(\mathrm{H}_{\mathrm{a}}\right)$, eco-social use $\left(\mathrm{H} 7_{\mathrm{b}}\right)$, and eco-social conservation $\left(\mathrm{H} 7_{\mathrm{c}}\right)$ intentions related to AFVs

2.3. Value-Belief-Norms (VBN) Theory. The Value-BeliefNorms (VBN) theory was proposed by Stern et al. [46]. Fundamental postulates of this theory include seven distinct but related constructs organised in a causal relationship to exclusively explain pro-environmental behaviours (PEB) [46]. Values, beliefs, and norms categorise the seven constructs of VBN. Values include biospheric, altruistic, and egoistic values; beliefs include the new ecological paradigm, awareness of consequences, and ascription of responsibility; and norms manifest in pro-environmental personal norms. These constructs lead to various behaviours ranging from environmental activism to private sphere behaviours. The fundamental assumption of this theory is that pro-environmental behaviour can be predicted via an array of values, beliefs, and norms connected in a causal chain process-values leading to beliefs, beliefs leading to norms, and norms ultimately shaping pro-environmental behaviour. The causal chain process of VBN is similar to that of TPB.

Applications of VBN theory can be found in several studies explaining pro-environmental behaviours, including willingness to pay for wildlife and travellers' pro-environmental behaviours in green lodging [47], students' car use for university routes [48], consumers' behaviour related to curtailment and innovation adoption $[8,10]$, and intentions to improve household energy efficiency [49].

These studies, along with many others, support the argument that the constructs of VBN are best placed on integrating with the TPB proposal for an extended framework predicting the targeted behaviour of this study $[1,50]$. 
2.4. Relationship between Environmental Values and Attitudes towards Behaviour. Personal value orientations are the building blocks of VBN theory that influence individuals' attitudes towards certain behaviours. According to Stern, Dietz, and Kalof [51], three distinct value orientations motivate behaviours pertinent to the environment: biospheric, altruistic, and egoistic values. Biospheric values are related to a concern for the environment and ecosphere. Decision-making influenced by biospheric values utilises an evaluation of behaviour regarding its impact on ecosystems [52]. Altruistic values motivate helping behaviours for general people and society and appraise the impact of engaging in (or refraining from) a particular behaviour on the wellbeing of other people [53]. However, unlike biospheric and altruistic values, the critical impetus of commitment to a particular behaviour, driven by egoistic values, is personal gain or self-interest [54].

A plethora of research available in the literature proposes causal relationships of egoistic, altruistic and biospheric values with attitudes towards certain behaviours (for instance, see $[55,56])$. Snelgar [54] proposed that egoistic values are negatively associated with attitude towards pro-environmental behaviours in his original conceptualisation of environmental values. This proposition was further augmented by some later studies [8]. However, a more recent stream of research suggested that egoistic values may relate positively to attitude towards pro-environmental behaviours and intentions to engage in such behaviours where the targeted behaviour is high-involvement, and the consequences of not engaging in pro-environmental behaviours may deem to hamper the self-interest [4]. In a similar vein, Chua et al. [55] also noted that egoistic values are positively associated with attitudes towards pro-environmental behaviours. Considering that the purchase and use of AFVs involve a lot of financial, social, and physical risk analysis and thus is a high-involvement decision, this study supports the later stream of research and proposes that egoistic values are positively associated attitude towards and intentions to engage in the purchase and responsible use of AFVs.

Contrary to complex interplay and conflicting evidence surrounding the relationship between egoistic values and attitude towards pro-environmental behaviours, there is a preponderance of the evidence and a consensus among researchers of this field, suggesting that biospheric and altruistic values are positively associated with attitude towards pro-environmental behaviours [57, 58]. Given the fundamental concept of biospheric values, it is pretty logical to argue that individuals who are more sensitive towards the environment and biosphere may tend to possess pro-ecological attitudes and therefore behave in a way that supports pro-environmental actions [59]. Though not directly associated with the environment, altruistic values reflect ethical behaviour from a social perspective and promote transsituational objectives of individuals to help others by preferring altruism over self-interest [60]. Therefore, a positive association of altruistic values with pro-environmental attitudes is evident in the literature $[17,61]$.

Based on the evidence presented above, the following hypotheses may be proposed:
$\mathrm{H} 8_{\mathrm{a}, \mathrm{b}, \mathrm{c}}$ : altruistic $\left(\mathrm{H}_{8 \mathrm{a}}\right)$, egoistic $\left(\mathrm{H}_{8 \mathrm{~b}}\right)$, and biospheric values $\left(\mathrm{H}_{8 \mathrm{c}}\right)$ are positively associated with attitude towards eco-socially conscious consumer behaviour related to AFVs.

$\mathrm{H} 9_{\mathrm{a}, \mathrm{b}, \mathrm{c}}$ : altruistic values are positively associated with the eco-social purchase $\left(\mathrm{H} 9_{\mathrm{a}}\right)$, eco-social use $\left(\mathrm{H} 9_{\mathrm{b}}\right)$, and eco-social conservation $\left(\mathrm{H} 9_{\mathrm{c}}\right)$ intentions related to AFVs

$\mathrm{H} 10_{\mathrm{a}, \mathrm{b}, \mathrm{c}}$ : egoistic values are positively associated with eco-social purchase $\left(\mathrm{H}_{10} 0_{\mathrm{a}}\right)$, eco-social use $\left(\mathrm{H} 10_{\mathrm{b}}\right)$, and eco-social conservation $\left(\mathrm{H} 10_{\mathrm{c}}\right)$ intentions related to AFVs

$\mathrm{H} 11_{\mathrm{a}, \mathrm{b}, \mathrm{c}}$ : biospheric values are positively associated with eco-social purchase $\left(\mathrm{H} 11_{\mathrm{a}}\right)$, eco-social use $\left(\mathrm{H} 11_{\mathrm{b}}\right)$, and eco-social conservation $\left(\mathrm{H} 11_{\mathrm{c}}\right)$ intentions related to AFVs

2.5. Religiosity and Sustainable Behaviour. Religion is a significant foundation of individuals' belief systems. According to a survey conducted in 2010 , more than $85 \%$ of the total world population, comprising adults and children, reflected some form of religious affiliation [62]. Studying religiosity (i.e., the impact of religious beliefs) is worthwhile in the quest to develop behavioural models to increase the acceptability of environment-friendly products to a broader consumer across the world. Muslims constituted around $22.32 \%$ (1.6 billion) of the total world population as of 2012, with rapidly increasing numbers of adherents in Europe and America [62]. Pakistan has the second-biggest Muslim population globally $(11.0 \%)$, with $96.0 \%$ of its population following Islam [62].

Religiosity is a significant factor affecting purchase decisions in religious communities. However, the inclusion of religion in modern paradigms of consumer behaviour has only received significant attention in a few cases. Many studies in the existing literature discuss the impact of religiosity on consumer behaviour. For instance, research on "Halal" products reports that there is a very strong commitment among Muslim consumers to choose products that are halal certified, and halal certification overrides every other attribute of products in the preference process [63-65]. A stream of consistent evidence suggests that religiosity is a highly influential factor when there is a direct relationship between products and the core beliefs of consumers, for instance, prohibition from consuming pork and liquor (see, for example, [66-70]). However, in cases where products are not directly relevant to core beliefs, for instance, the purchase and use of environment-friendly cars, the role of religious beliefs are not abundantly researched. Nevertheless, a small number of fascinating studies, specifically in religiosity and pro-environmental behaviours, can be traced in the literature that can help conceptualise the relationship between religiosity and eco-socially conscious behaviours.

One such study conducted on students in the US refuted a false belief that religiosity reduces concern for the environment among Judeo-Christians. The study reported that consumers with religious beliefs are no different from those who do not hold religious beliefs regarding attitudes towards 
pro-environmental behaviours. In another study conducted in Mexico in the religious context of Christianity, Felix and Braunsberger [71] found a powerful positive relationship between intrinsic religious orientation (IRO), environmental attitudes, and propensity to buy environmentfriendly products. Religious beliefs reduce the materialistic evaluations of consumers and raise concern for others, including the environment. For instance, Pace [72] investigated the specific tenets of the Buddhist religion and found that religiosity reduces materialism. The evidence from these studies supports the idea that religiosity neutralises egoistic values and promotes altruistic behaviour, leading to concern for the environment and ultimately translating into proenvironmental behaviours.

Finally, an intriguing study by Hope and Jones [73] suggests the need to rethink the impact of religious beliefs, from different religious faiths, on pro-environmental behaviour. In their study, conducted in the UK, Hope and Jones [73] provided a comparative account of Christianity, Islam, and nonreligious communities. They showed that both Christians and Muslims showed low urgency to address environmental issues compared with secular communities. They added that Muslim respondents showed greater resistance towards accepting environment-friendly technology due to specific beliefs about life after death and divine intervention.

However, Islamic directives on the protection of the environment and conservation of energy depict a different picture. Abdul-Matin [74] extracted specific texts relating to this from the Holy Qur'an, such as that "In Islam, all humans are considered stewards of the Earth, and in the Qur'an, God sets forward clear principles about this stewardship that include taking care of oneself, of others, and of the planet." In providing a further explanation, Abdul-Matin [74] quotes six fundamental principles of Islam that direct people to protect the natural habitat as signs of God, act as stewards of the Earth and maintain its natural balance, and be protectors of the planet and move with justice ([74], p. 5). In both letter and spirit, the Islamic teachings direct Muslims to protect the environment, conserve energy, and prefer products that augment this more prominent cause.

In the light of literature summarised above, it may be proposed that

H12: religiosity is positively associated with attitude towards eco-socially conscious consumer behaviour related to AFVs

Figure 1 shows the conceptual model of the study based on the literature cited above.

\section{Methodology}

3.1. Measures. The questionnaire used in this study was based on the measurement of constructs of the original TPB proposal as well as additional constructs (i.e., egoistic, altruistic, and biospheric values) from Value-Belief-Norms (VBN) theory $[46,75]$. A series of elicitation interviews were carried out to measure belief sets and consequent constructs, including attitudes, norms, and perceived behavioural control. The resulting measurement elements were then cross-validated with existing studies that used TPB constructs for a similar type of behaviour (i.e., eco-social purchase intentions, eco-social conservation intentions, and eco-social use intentions) in the existing literature.

The interview and literature review process resulted in a total of 19 items representing four different type of beliefs sets (behavioural beliefs: 4 items, $\alpha=0.829$; control beliefs: 4 items, $\alpha=0.788$; normative descriptive beliefs: 5 items, $\alpha=0.841$; normative injunctive beliefs: 4 items, $\alpha=0.794$ ). These items are coherent with the questionnaire elements used in some existing studies of a similar kind (see, for instance, [37, 39]). Response to the questionnaire statements was taken on a 7-point Likert scale anchored by "strongly disagree" (1) to "strongly agree" (7).

The direct measures of attitude towards behaviour ( 6 items, $\alpha=0.772$ ), subjective injunctive norms (6 items, $\alpha=0.826$ ), subjective descriptive norms ( 4 items, $\alpha=0.779$ ), and perceived behavioural control ( 6 items, $\alpha=0.844$ ) were also utilised, again following the measurement recommendations of Fishbein and Ajzen [75] and in concordance with the existing literature $[36,37,39]$. Response scale was kept similar as for belief sets.

Given this study's context, three different types of behavioural intentions (purchase, use, and conservation intentions) pertaining to the use and purchase of personal cars were conceptualised and measured. The measurement of ecosocially conscious consumers' behavioural intentions was taken from the study of Saleem et al. [2]. They defined ecosocial purchase as buying a car with better environmental performance, eco-social use as ethical and pro-environmental use of private cars to minimise any negative environmental impacts, and eco-social conservation as self-motivated and directed behaviours towards car maintenance so as to ensure the conservation of resources (for instance fuel) to reduce emissions or other types of environmental pollution. Consequently, 9 items were used to measure consumers behavioural intentions (eco-social purchase intentions: 3 items, $\alpha=0.837$; eco-social use intentions: 3 items, $\alpha=0.759$; ecosocial conservation intentions: 3 items, $\alpha=0.867)$. Again, a 7point Likert-based response scale was utilised to gauge responses for constructs explained in the earlier sections.

Finally, the additional constructs used to extend the theory of planned behaviour (egoistic, altruistic, and biospheric values) in this study were conceptually measured following the theoretical lines provided by Stern [76]. Measured on a 7-point Likert-based scale, five items each for the three distinct value sets were utilised to gauge individuals' value orientations (altruistic values: 5 items, $\alpha=0.827$; egoistic values: 5 items, $\alpha=0.893$; biospheric values: 5 items, $\alpha=0.819$ ). The items were adapted from, and are extensively used in, existing studies $[57,77,78]$.

The description of the measurement instrument is provided in Table 1.

3.1.1. Participants and Procedure. Data were collected from the customers of three big automobile manufacturers (Honda Cars Pakistan, Indus Toyota Motors, Suzuki Motors 


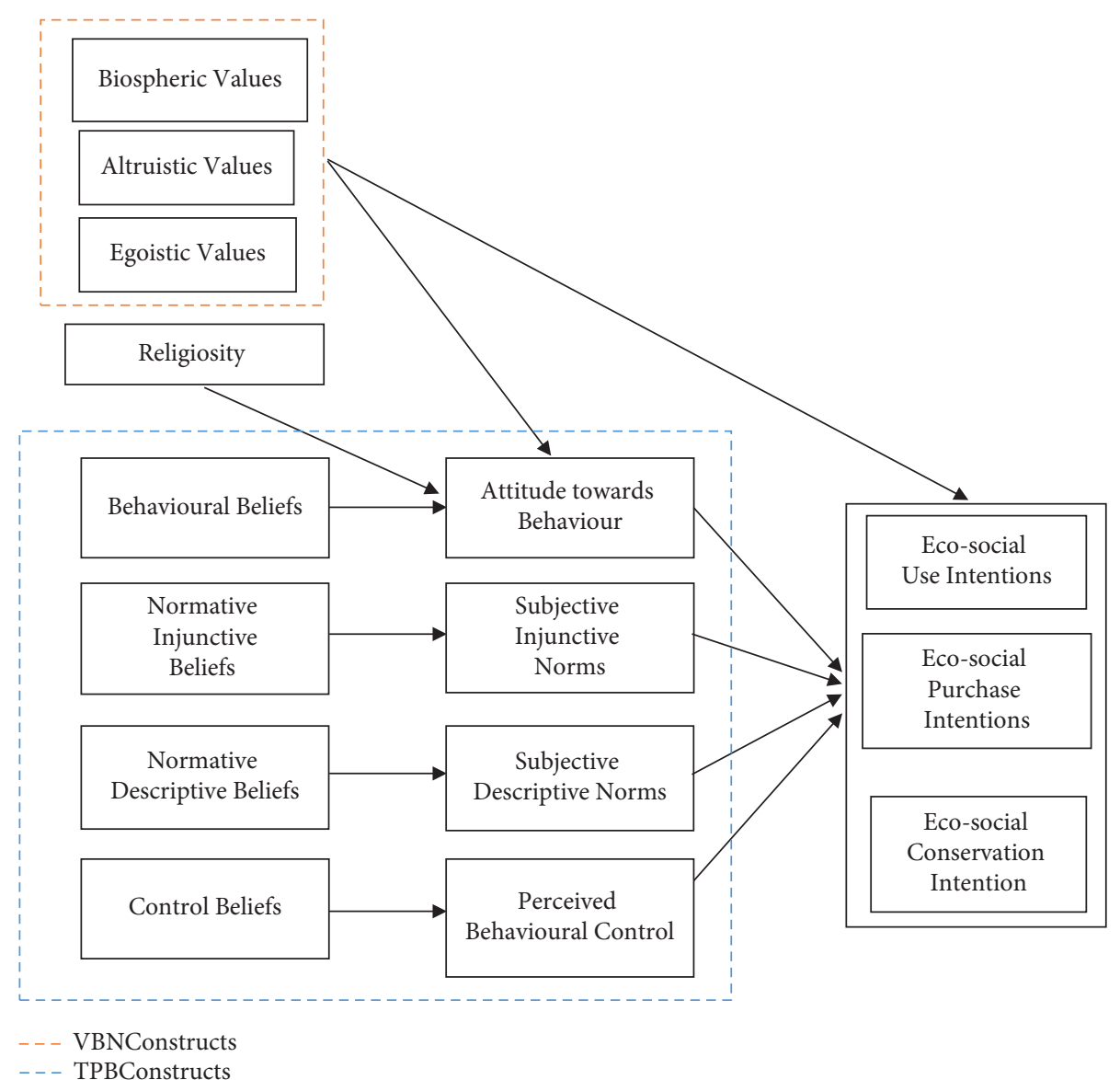

Figure 1: Extended model of theory of planned behaviour.

TABLE 1: Description of the measurement instrument ${ }^{\mathrm{a}}$.

\begin{tabular}{|c|c|c|}
\hline Constructs & Items & Description of items \\
\hline 1. Altruistic value & $\begin{array}{l}\text { AltVal1 } \\
\text { AltVal3 } \\
\text { AltVal } 4 \\
\text { AltVal5 }\end{array}$ & $\begin{array}{l}\text { Pollution generated here harms people all over the Earth } \\
\text { The effects of pollution on public health are worse than we realize } \\
\text { Environmental protection helps people have a better quality of life } \\
\text { Environmental protection benefits everyone }\end{array}$ \\
\hline 5. Biospheric value & $\begin{array}{l}\text { BioVal1 } \\
\text { BioVal2 } \\
\text { BioVal5 }\end{array}$ & $\begin{array}{l}\text { Modern development threatens wildlife } \\
\text { Over the next several decades, thousands of species of plants and animals will become extinct } \\
\text { The balance of nature is delicate and easily upset }\end{array}$ \\
\hline 8. Egoistic value & $\begin{array}{l}\text { EgoVal1 } \\
\text { EgoVal4 } \\
\text { EgoVal5 }\end{array}$ & $\begin{array}{l}\text { A clean environment provides me with better opportunities for recreation } \\
\text { Environmental protection is beneficial to my health } \\
\text { Environmental protection provides a better world for me and my children }\end{array}$ \\
\hline 10. Normative injunctive & NrInBl1 & $\begin{array}{l}\text { When it comes to buying a car, I want to choose one which I believe most people who are } \\
\text { important to me think I should choose } \\
\text { I want to choose mode of transportation which I believe most people who are important to me } \\
\text { think I should choose }\end{array}$ \\
\hline beliefs & NrInjBl4 & $\begin{array}{l}\text { When it comes to fuel economic ways of driving a car, I want to follow what I believe people } \\
\text { important to me think I should do } \\
\text { Considering their fuel conservation impact, while I choose tires for my car, I want to consider } \\
\text { the advice of people who are important to me }\end{array}$ \\
\hline
\end{tabular}


TABle 1: Continued.

\begin{tabular}{|c|c|c|}
\hline Constructs & Items & Description of items \\
\hline \multirow{5}{*}{$\begin{array}{l}\text { 14. Normative descriptive } \\
\text { beliefs }\end{array}$} & NrDBl1 & $\begin{array}{c}\text { I believe that people who are important to me are planning to engage in activities for } \\
\text { environmental protection }\end{array}$ \\
\hline & $\mathrm{NrDB} 2$ & $\begin{array}{l}\text { I believe that people who are important to me are planning to adopt practice that help } \\
\text { conservation of resources for environmental reasons }\end{array}$ \\
\hline & $\mathrm{NrDB} 33$ & $\begin{array}{c}\text { I believe that people who are important to me are planning to reduce use of personal car for } \\
\text { environmental reasons }\end{array}$ \\
\hline & $\mathrm{NrDBl} 4$ & $\begin{array}{l}\text { I believe that people who are important to me are inclined to drive ethically in a way that is } \\
\text { good for fuel economy }\end{array}$ \\
\hline & $\mathrm{NrDB} 15$ & $\begin{array}{c}\text { I believe that people who are important to me are planning to use electric vehicle for } \\
\text { environment }\end{array}$ \\
\hline \multirow{3}{*}{ 19. Control beliefs } & CntlBl1 & $\begin{array}{l}\text { I believe I have enough options to select from in electric car categories while I choose to buy } \\
\text { one }\end{array}$ \\
\hline & CntlBl2 & I believe I have public transportation options available if I consider to use \\
\hline & CntlBl4 & I believe I have ways to reduce the use of personal car for environmental reasons \\
\hline \multirow{3}{*}{$\begin{array}{l}\text { 22. Attitude towards } \\
\text { behaviour }\end{array}$} & AttoBeh1 & For me, buying an environmentally friendly car is logical \\
\hline & AttoBeh2 & For me, using public transport instead of personal car is a wise decision \\
\hline & AttoBeh4 & For me, carpooling instead of using personal car is rational \\
\hline \multirow{4}{*}{ 25. Behavioural beliefs } & BehBlf1 & $\begin{array}{l}\text { I believe my selecting a car with high rear axle ration will help reduce negative impacts of } \\
\text { personal cars on environment }\end{array}$ \\
\hline & BehBlf2 & I believe if I avoid using radial tires, it will help conserve fuel \\
\hline & BehBlf4 & I believe if I abide by speed limits, it will help me reduce fuel consumption \\
\hline & BehBlf5 & I believe if I buy electric vehicles, it will help me protect environment from car exhausts \\
\hline \multirow{5}{*}{$\begin{array}{l}\text { 26. Subjective injunctive } \\
\text { norms }\end{array}$} & SbInNr1 & People who are important to me support me when I drive environment-friendly car \\
\hline & SbInNr2 & People who are important to me try to convince me to drive an environment-friendly car \\
\hline & SbInNr3 & Most people who are important to me think I should buy an environment-friendly car \\
\hline & SbInNr5 & $\begin{array}{l}\text { People whose opinion I value would prefer me to do carpooling whenever possible for } \\
\text { commuting }\end{array}$ \\
\hline & SbInNr6 & $\begin{array}{c}\text { Many of the people that are important to me insinuated that I should consider environmental } \\
\text { protection while buying a car }\end{array}$ \\
\hline \multirow{3}{*}{$\begin{array}{l}\text { 27. Subjective descriptive } \\
\text { norms }\end{array}$} & SbDNr1 & Most of the people that are important to me own environment-friendly cars \\
\hline & $\mathrm{SbDNr} 2$ & $\begin{array}{l}\text { Most of the people that are important to me are considering to buy environmentally friendly } \\
\text { car }\end{array}$ \\
\hline & SbDNr3 & Most of the people that are important to me do carpooling for commuting \\
\hline \multirow{5}{*}{$\begin{array}{l}\text { 29. Perceived behavioural } \\
\text { control }\end{array}$} & $\mathrm{PBC} 2$ & If I wanted, I could buy an environmentally friendly car \\
\hline & PBC3 & $\begin{array}{c}\text { It was mostly up to me whether I would prefer public transport instead of personal car for } \\
\text { commuting }\end{array}$ \\
\hline & $\mathrm{PBC} 4$ & It was mostly up to me whether I would do carpooling for commuting \\
\hline & PBC5 & If I wanted, I could use public transport for commuting \\
\hline & PBC6 & If I wanted, I could do carpooling for commuting \\
\hline \multirow{3}{*}{$\begin{array}{l}\text { 34. Eco-social purchase } \\
\text { intentions }\end{array}$} & ESCBPInt1 & I intend to buy an alternative fuel vehicle even if its quality is lower than a conventional car \\
\hline & ESCBPInt2 & $\begin{array}{l}\text { I intend to buy an alternative fuel vehicle even if its performance is lower than a conventional } \\
\text { car }\end{array}$ \\
\hline & ESCBPInt3 & I intend to buy an alternative fuel vehicle even if it has a less appealing design \\
\hline \multirow{3}{*}{$\begin{array}{l}\text { 37. Eco-social conservation } \\
\text { intentions }\end{array}$} & ESCBCInt1 & $\begin{array}{c}\text { I intend to select a car with a high rear axle ratio for that produces least friction and saves } \\
\text { energy }\end{array}$ \\
\hline & ESCBCInt2 & I intend to avoid using wide thread tires for that cause road friction and consume more fuel \\
\hline & ESCBCInt3 & I intend to consider using radial tires for that help to preserve fuel resource \\
\hline \multirow{4}{*}{ 40. Eco-social use intentions } & ESCBUInt1 & $\begin{array}{c}\text { I intend to choose the one with better environmental performance, if I have multiple car } \\
\text { options }\end{array}$ \\
\hline & ESCBUInt2 & $\begin{array}{c}\text { Knowing that excessive speed is inefficient and requires more energy to stop the car, I intend } \\
\text { to consider observing speed limits }\end{array}$ \\
\hline & ESCBUInt3 & $\begin{array}{l}\text { Knowing that excessive speed is inefficient and requires more energy to stop the car, I intend } \\
\text { to consider observing steady pace }\end{array}$ \\
\hline & ESCCBA4 & I have been carpooling for office commute for the last couple of months \\
\hline \multirow{5}{*}{ 44. Religiosity } & Rlgsty2 & In my life, I experience the presence of the divine (i.e., God) \\
\hline & Rlgsty4 & Nothing is as important to me as serving God as best as I know how \\
\hline & Rlgsty6 & My religious beliefs are what really lie behind my whole approach to life \\
\hline & Rlgsty7 & I try hard to carry my religion over into all my other dealings in life \\
\hline & Rlgsty8 & One should seek God's guidance when making every important decision \\
\hline
\end{tabular}

Note: ${ }^{a}$ items retained after deleting those with low loadings are presented. 
Pakistan, having $86 \%$ marketing share) having dealerships in eight big cities of Pakistan. Through proportionate stratified random sampling, a nationally representative sample of Pakistani automobile customers was selected, yielding a total of 1372 useable responses. Data collection was carried out at the dealerships of the automobile distributors with the help of data collection assistants by using the pen and paper method. The respondents were first provided with an information sheet outlining the purpose of the project, an explanation regarding what AFVs meant in the context of this current project, and other details regarding the anonymity of respondents' identity and consent to take part in the project. All permissions and consents were taken in writing prior to data collection. Formal approval to conduct activities of this research project was granted by the Human Research Ethics Committee of James Cook University Australia under reference number H6869. The profile of respondents summarised in The profile of the respondents summarized in Table 2 shows that the sample mainly consisted of young respondents (19-26: 63.6\%, 26-33: $18.7 \%)$, slightly male-dominant $(55.7 \%)$, over 665 had income in the bracket of PKR 45000-75000 (under USD 600), and over $58 \%$ had bachelors or higher degree (Bachelor's degree: 11.8\%, Master's degree: 46.8\%). These statistics correspond to the national population figures in Pakistan (over $60 \%$ population under 30 years of age, around $51 \%$ male, and an average income of about USD 600) $[79,80]$.

\section{Analysis}

The data analysis was conducted by using SPSS v. 25.0 and SmartPLS v. 3.2.8 programs. Exploratory Factor Analysis (EFA) and Partial Least Squares Structural Equation Modelling (PLS-SEM) approaches were employed to test measurement and structural models, respectively. Before primary data analyses, data were tested for certain biases.

PLS-SEM is a modern technique used to analyse complex data involving multiple paths in an array of direct and indirect relationships. Notably, for application of structural equation modelling, PLS-SEM has been regarded as more accurate, flexible for sample size, and tolerant to data normality violations and accommodates simultaneous analysis of multiple mediations [81, 82].

\subsection{Data Biases}

4.1.1. Missing Values and Outliers. Analysis of missing values is an essential concern in quantitative studies based on survey methods [83]. Missing value analysis using SPSS v. 25.0 highlighted no missing values in any of the constructs or items of any constructs. This was not surprising because the data collection method was driven by personal contact by the research assistants with the respondents, which led to more assistance available while the subjects were responding to the survey, hence eliminating no or partial responses.

Outliers are scores that appear different and dissimilar from the other data in the total dataset or in the dataset of constructs [84]. As outliers are known to cause serious bias in estimates, various tests were conducted to identify the outliers in the data. Using boxplots and $z$-scores, it was found that the data were free of extreme values, hence appropriate to proceed with the subsequent principal analysis.

4.1.2. Common Method Bias. This study applied Harman's single factor test to detect common method variance (CMV), which causes common method bias [85]. All survey items were used to run the test, and the results showed that no single factor alone explained variance of greater than $25 \%$, confirming that CMB is not a critical issue for this study [85]. The study further verified the nonexistence of CMB following the proposal of Costello and Osborne [86], who noted that "variance inflation factor (VIF) values of greater than 3.3 are an indication of pathological collinearity as well as common method bias." A factor level assessment of VIFs for all constructs was conducted to verify this condition, which showed that VIFs for all constructs were way below the threshold value of 3.3. Therefore, the data can be considered free of CMB.

4.1.3. Endogeneity. As PLS-SEM follows regression-based methods, appraisal of the potential existence of endogeneity is vital to establish the validity of coefficient estimates [84]. Following the guidelines of [84], this study utilised the Gaussian copula approach of [83] by modelling the correlation between the scores of lower-order endogenous constructs and error terms employing a copula. Results confirmed that neither copulas were significant; thus, endogeneity is not present [83].

4.2. Measurement Model Evaluation. Principal component analysis (PCA) was first conducted with the varimax rotation method [86]. Preliminary results showed the suitability of data for performing factor analysis as the Kaiser-Meyer-Olkin measure was within range $(\mathrm{KMO}=0.88)$ and the Bartlett test was statistically significant $(p<0.05)$ [87]. Further investigation involved scrutiny of factor loadings, following Hair [88], who suggested removing items with factor loadings lower than 0.40 . The resulting items with their respective constructs and factor loadings are reported in Table 3.

4.2.1. Reliability and Validity. This study examined composite reliability (CR) and Cronbach alpha for reliability $[89,90]$, average variance extracted (AVEs) for convergent validity [91], and heterotrait-monotrait $\left(\mathrm{HTMT}_{0.85}\right)$ ratio of correlation between the constructs for discriminant validity [92]. The results reported in Tables 3 and 4 show that constructs are valid (AVEs: 0.576-0.823; HTMT $_{0.85}$ : 0.162-0.802) and reliable (CR: 0.861-0.933; Cronbach alpha: $0.759-0.895)$.

4.3. Structural Model Evaluation. The estimates of direct effects are summarised in Table 5, and accordingly, the results of hypotheses are in Table 6. 
TABLE 2: Respondent's profile.

\begin{tabular}{|c|c|c|c|}
\hline \multirow{2}{*}{ Variable } & \multirow{2}{*}{ Category } & \multicolumn{2}{|c|}{ Distribution } \\
\hline & & Frequency & Percentage \\
\hline \multirow{7}{*}{ Age } & $19-26$ & 872 & 63.6 \\
\hline & $>26-33$ & 256 & 18.7 \\
\hline & $>33-40$ & 156 & 11.4 \\
\hline & $>40-47$ & 12 & 0.9 \\
\hline & $>47-54$ & 44 & 3.2 \\
\hline & $>54-61$ & 24 & 1.7 \\
\hline & $>61$ & 8 & 0.6 \\
\hline \multirow{2}{*}{ Gender } & Male & 764 & 55.7 \\
\hline & Female & 608 & 44.3 \\
\hline \multirow{7}{*}{ Income* } & $45000-55000$ & 538 & 39.2 \\
\hline & $>55000-65000$ & 130 & 9.5 \\
\hline & $>65000-75000$ & 232 & 16.9 \\
\hline & $>75000-85000$ & 94 & 6.9 \\
\hline & $>85000-95000$ & 114 & 8.3 \\
\hline & $>95000-105000$ & 100 & 7.3 \\
\hline & $>105000$ & 164 & 12.0 \\
\hline \multirow{2}{*}{ Car possession } & Yes, have a car & 852 & 62.1 \\
\hline & No, I do not have a car & 520 & 37.9 \\
\hline \multirow{4}{*}{ Marital status } & Single & 966 & 70.4 \\
\hline & Married & 372 & 27.1 \\
\hline & Divorced & 28 & 2.0 \\
\hline & Widowed & 6 & 0.4 \\
\hline \multirow{5}{*}{ Occupation } & Landlord & 160 & 11.7 \\
\hline & Businessman & 180 & 13.1 \\
\hline & Private job & 702 & 51.2 \\
\hline & Government job & 310 & 22.6 \\
\hline & Armed forces & 20 & 1.5 \\
\hline \multirow{8}{*}{ Education } & $<$ High School & 22 & 1.5 \\
\hline & High school & 66 & 4.8 \\
\hline & Bachelor's degree & 162 & 11.8 \\
\hline & Master's degree & 642 & 46.8 \\
\hline & MBBS and BDS & 372 & 27.1 \\
\hline & DVM & 36 & 2.6 \\
\hline & $\mathrm{BE}$ & 6 & 0.4 \\
\hline & Others & 66 & 4.8 \\
\hline
\end{tabular}

Note: ${ }^{*}$ income is in Pakistan rupee (PKR); MBBS = Bachelor of Medicine and bachelor of Surgery; BDS = Bachelor of Dental Surgery; DVM= Doctor of Veterinary Medicine; $\mathrm{BE}=$ Bachelor of Engineering.

Results of the extended TPB model show that all salient beliefs positively led to their corresponding attitude level constructs $\quad\left(\beta_{\text {behavioural }}\right.$ beliefs $=0.171$, CIs $=0.114-0.228$; $\beta_{\text {normative injunctive beliefs }}=0.617$, CIs $=0.578-0.651 ; \beta_{\text {normative }}$ descriptive $\quad$ beliefs $=0.438, \quad$ CIs $=0.380-0.484 ; \quad \beta_{\text {control }}$ beliefs $=0.471$, CIs $=0.427-0.516$ ). This leads us to accept our hypotheses H1-H3. Similarly, the subjective descriptive norms are found positively associated with all three facets of eco-social behavioural intentions related to AFVs, i.e., ecosocial purchase $\left(\mathrm{H} 4_{\mathrm{a}}: \beta_{\text {eco-social purchase intentions }}=0.230\right.$, CIs $=0.164-0.296)$, eco-social use $\left(\mathrm{H}_{\mathrm{b}}: \beta_{\text {eco-social }}\right.$ use intentions $=0.155$, CIs $=0.098-0.212$ ), and eco-social conservation $\left(\mathrm{H} 4_{\mathrm{c}}: \quad \beta_{\text {eco-social }}\right.$ conservation intentions $=0.149$, $\mathrm{CIs}=0.092-0.206$ ); hence, hypotheses $\mathrm{H} 4_{\mathrm{a}}, \mathrm{H} 4_{\mathrm{b}}$, and $\mathrm{H} 4_{\mathrm{c}}$ are also accepted.

Slightly different to the results of subjective descriptive norms, subjective injunctive norms are found not associated with eco-social purchase intentions related to $\mathrm{AFVs}\left(\mathrm{H}_{\mathrm{a}}\right.$ : $\beta_{\text {eco- }}$ social purchase intentions $=0.041, \mathrm{CIs}=-0.026-0.105)$ but have positive significant association with the other two dimensions of eco-social behavioural intentions related to AFVs, i.e., ecosocial use $\left(\mathrm{H} 5_{\mathrm{b}}: \beta_{\text {eco-social }}\right.$ use intentions $=0.154$, CIs $=0.087-0.218)$ and eco-social conservation ( $\mathrm{H}_{\mathrm{c}}$ : $\beta_{\text {eco-social }}$ conservation intentions $=0.210$, CIs $=0.139-0.272)$. Therefore, hypothesis $\mathrm{H} 5_{\mathrm{a}}$ is rejected, but $\mathrm{H} 5_{\mathrm{b}}$ and $\mathrm{H} 5_{\mathrm{c}}$ are accepted.

Results further suggest that the attitude towards behaviour positively leads to eco-social purchase $\left(\mathrm{H}_{\mathrm{a}}\right.$ : $\beta_{\text {eco-social }}$ purchase intentions $=0.079, \mathrm{CIs}=0.013-0.163)$, eco-social use $\left(\mathrm{H} 6_{\mathrm{b}}: \beta_{\text {eco-social }}\right.$ use intentions $\left.=0.167, \mathrm{CIs}=0.111-0.230\right)$, and eco-social conservation $\left(\mathrm{H}_{\mathrm{c}}\right.$ : $\beta_{\text {eco-social }}$ conservation intentions $=0.151, \quad C I s=0.099-0.207)$ intentions related to AFVs; hence, our corresponding hypotheses are accepted. Contrarily, however, perceived behavioural control is found to have no significant association with eco-social purchase $\left(\mathrm{H}_{\mathrm{a}} \mathrm{a} \beta_{\text {eco-social }}\right.$ purchase intentions $=-0.020$, CIs $\left.=-0.095-0.063\right)$ and eco-social use intentions $\left(\mathrm{H} 7_{\mathrm{b}}\right.$ : $\beta_{\text {eco-social }}$ use 
TABLE 3: Standardized loadings, composite reliability, and AVEs of constructs.

\begin{tabular}{|c|c|c|c|c|c|}
\hline Constructs & Items & Loadings & AVE & $\alpha$ & $\mathrm{CR}$ \\
\hline Behavioural beliefs & $\begin{array}{l}\text { BehBlf1 } \\
\text { BehBlf2 } \\
\text { BehBlf4 } \\
\text { BehBlf5 }\end{array}$ & $\begin{array}{l}0.747 \\
0.825 \\
0.869 \\
0.805 \\
\end{array}$ & 0.660 & 0.829 & 0.886 \\
\hline Normative injunctive beliefs & $\begin{array}{l}\text { NrmInBlf1 } \\
\text { NrmInBlf2 } \\
\text { NrmInBlf3 } \\
\text { NrmInBlf4 } \\
\end{array}$ & $\begin{array}{l}0.748 \\
0.808 \\
0.783 \\
0.801 \\
\end{array}$ & 0.617 & 0.794 & 0.866 \\
\hline Normative descriptive beliefs & $\begin{array}{l}\text { NrmDBlf1 } \\
\text { NrmDBlf2 } \\
\text { NrmDBlf3 } \\
\text { NrmDBlf4 } \\
\text { NrmDBlf5 }\end{array}$ & $\begin{array}{l}0.783 \\
0.823 \\
0.757 \\
0.782 \\
0.762 \\
\end{array}$ & 0.611 & 0.841 & 0.887 \\
\hline Control beliefs & $\begin{array}{l}\text { CntrlBlf1 } \\
\text { CntrlBlf2 } \\
\text { CntrlBlf4 } \\
\end{array}$ & $\begin{array}{l}0.835 \\
0.891 \\
0.787 \\
\end{array}$ & 0.704 & 0.788 & 0.877 \\
\hline Attitude towards behaviour & $\begin{array}{l}\text { AtttowBeh1 } \\
\text { AtttowBeh2 } \\
\text { AtttowBeh4 }\end{array}$ & $\begin{array}{l}0.841 \\
0.864 \\
0.779 \\
\end{array}$ & 0.687 & 0.772 & 0.868 \\
\hline Subjective injunctive norms & $\begin{array}{l}\text { SbInNr1 } \\
\text { SbInNr2 } \\
\text { SbInNr3 } \\
\text { SbInNr5 } \\
\text { SbInNr6 }\end{array}$ & $\begin{array}{l}0.757 \\
0.846 \\
0.749 \\
0.735 \\
0.749 \\
\end{array}$ & 0.591 & 0.826 & 0.878 \\
\hline Subjective descriptive norms & $\begin{array}{l}\text { SubNormDes1 } \\
\text { SubNormDes2 } \\
\text { SubNormDes3 }\end{array}$ & $\begin{array}{l}0.793 \\
0.831 \\
0.870 \\
\end{array}$ & 0.692 & 0.779 & 0.871 \\
\hline Perceived behavioural control & $\begin{array}{l}\text { PercBehCntrl2 } \\
\text { PercBehCntrl3 } \\
\text { PercBehCntr4 } \\
\text { PercBehCntrl5 } \\
\text { PercBehCntrl6 } \\
\end{array}$ & $\begin{array}{l}0.755 \\
0.793 \\
0.832 \\
0.752 \\
0.792 \\
\end{array}$ & 0.617 & 0.844 & 0.889 \\
\hline Eco-social purchase intentions & $\begin{array}{l}\text { ESCCBPInt1 } \\
\text { ESCCBPInt2 } \\
\text { ESCCBPInt3 } \\
\end{array}$ & $\begin{array}{l}0.875 \\
0.848 \\
0.882 \\
\end{array}$ & 0.754 & 0.837 & 0.902 \\
\hline Eco-social conservation intentions & $\begin{array}{l}\text { ESCCBCInt1 } \\
\text { ESCCBCInt2 } \\
\text { ESCCBCInt3 }\end{array}$ & $\begin{array}{l}0.890 \\
0.891 \\
0.887 \\
\end{array}$ & 0.790 & 0.867 & 0.919 \\
\hline Eco-social use intentions & $\begin{array}{l}\text { ESCCBUInt1 } \\
\text { ESCCBUInt2 } \\
\text { ESCCBUInt3 }\end{array}$ & $\begin{array}{l}0.856 \\
0.881 \\
0.721 \\
\end{array}$ & 0.676 & 0.759 & 0.861 \\
\hline Actual behavioural control & $\begin{array}{l}\text { ActBehCntrl1 } \\
\text { ActBehCntrl2 } \\
\text { ActBehCntrl3 } \\
\text { ActBehCntrl4 }\end{array}$ & $\begin{array}{l}0.722 \\
0.828 \\
0.871 \\
0.802 \\
\end{array}$ & 0.652 & 0.820 & 0.882 \\
\hline Eco-socially conscious consumer behaviour & $\begin{array}{l}\text { ESCCB1 } \\
\text { ESCCB2 } \\
\text { ESCCB3 } \\
\text { ESCCB4 } \\
\text { ESCCB6 } \\
\end{array}$ & $\begin{array}{l}0.788 \\
0.801 \\
0.735 \\
0.721 \\
0.747 \\
\end{array}$ & 0.576 & 0.816 & 0.872 \\
\hline Egoistic values & $\begin{array}{l}\text { EgoVal1 } \\
\text { EgoVal4 } \\
\text { EgoVal5 } \\
\end{array}$ & $\begin{array}{l}0.916 \\
0.930 \\
0.876 \\
\end{array}$ & 0.823 & 0.893 & 0.933 \\
\hline Altruistic values & $\begin{array}{l}\text { AltVal1 } \\
\text { AltVal3 } \\
\text { AltVal4 } \\
\text { AltVal5 }\end{array}$ & $\begin{array}{c}0.839 \\
0.805 \\
0.800 \\
0.799\end{array}$ & 0.658 & 0.827 & 0.885 \\
\hline
\end{tabular}


TABle 3: Continued.

\begin{tabular}{|c|c|c|c|c|c|}
\hline Constructs & Items & Loadings & AVE & $\alpha$ & $\mathrm{CR}$ \\
\hline \multirow{3}{*}{ Biospheric values } & BioVal1 & 0.861 & \multirow{3}{*}{0.732} & \multirow{3}{*}{0.819} & \multirow{3}{*}{0.891} \\
\hline & BioVal2 & 0.864 & & & \\
\hline & BioVal5 & 0.842 & & & \\
\hline \multirow{5}{*}{ Religiosity } & Rlgsty2 & 0.813 & \multirow{5}{*}{0.705} & \multirow{5}{*}{0.895} & \multirow{5}{*}{0.923} \\
\hline & Rlgsty 4 & 0.871 & & & \\
\hline & Rlgsty6 & 0.863 & & & \\
\hline & Rlgsty7 & 0.838 & & & \\
\hline & Rlgsty8 & 0.811 & & & \\
\hline
\end{tabular}

Note: ESCCB = eco-socially conscious consumers' behavioural intentions.

TABLE 4: HTMT 0.85 ratios and square root of AVEs.

\begin{tabular}{|c|c|c|c|c|c|c|c|c|c|c|c|c|c|c|c|c|c|}
\hline Constructs & $\sqrt{ }$ AVEs & A & $\mathrm{B}$ & $\mathrm{C}$ & $\mathrm{D}$ & $\mathrm{E}$ & $\mathrm{F}$ & G & $\mathrm{H}$ & I & $\mathrm{J}$ & K & $\mathrm{L}$ & $\mathrm{M}$ & $\mathrm{N}$ & $\mathrm{O}$ & $\mathrm{P}$ \\
\hline $\begin{array}{l}\text { A. Behavioural } \\
\text { beliefs }\end{array}$ & 0.813 & 1 & & & & & & & & & & & & & & & \\
\hline $\begin{array}{l}\text { B. Normative } \\
\text { injunctive } \\
\text { beliefs }\end{array}$ & 0.785 & 0.518 & 1 & & & & & & & & & & & & & & \\
\hline $\begin{array}{l}\text { C. Normative } \\
\text { descriptive } \\
\text { beliefs }\end{array}$ & 0.782 & 0.667 & 0.660 & 1 & & & & & & & & & & & & & \\
\hline $\begin{array}{l}\text { D. Control } \\
\text { beliefs }\end{array}$ & 0.839 & 0.531 & 0.559 & 0.449 & 1 & & & & & & & & & & & & \\
\hline $\begin{array}{l}\text { E. Attitude } \\
\text { towards } \\
\text { behaviour }\end{array}$ & 0.829 & 0.552 & 0.515 & 0.759 & 0.490 & 1 & & & & & & & & & & & \\
\hline $\begin{array}{l}\text { F. Subjective } \\
\text { injunctive } \\
\text { norms }\end{array}$ & 0.769 & 0.583 & 0.755 & 0.626 & 0.566 & 0.591 & 1 & & & & & & & & & & \\
\hline $\begin{array}{c}\text { G. Subjective } \\
\text { descriptive } \\
\text { norms }\end{array}$ & 0.832 & 0.420 & 0.548 & 0.527 & 0.597 & 0.519 & 0.598 & 1 & & & & & & & & & \\
\hline $\begin{array}{l}\text { H. Perceived } \\
\text { behavioural } \\
\text { control }\end{array}$ & 0.785 & 0.515 & 0.558 & 0.613 & 0.574 & 0.686 & 0.630 & 0.644 & 1 & & & & & & & & \\
\hline $\begin{array}{l}\text { I. Eco-social } \\
\text { purchase } \\
\text { intentions }\end{array}$ & 0.868 & 0.162 & 0.285 & 0.600 & 0.258 & 0.269 & 0.251 & 0.367 & 0.253 & 1 & & & & & & & \\
\hline $\begin{array}{l}\text { J. Eco-social } \\
\text { conservation } \\
\text { intentions }\end{array}$ & 0.889 & 0.533 & 0.607 & 0.627 & 0.607 & 0.623 & 0.629 & 0.527 & 0.618 & 0.280 & 1 & & & & & & \\
\hline $\begin{array}{l}\text { K. Eco-social } \\
\text { use intentions }\end{array}$ & 0.822 & 0.510 & 0.631 & 0.704 & 0.507 & 0.633 & 0.604 & 0.560 & 0.578 & 0.426 & 0.710 & 1 & & & & & \\
\hline $\begin{array}{l}\text { L. Eco-socially } \\
\text { conscious } \\
\text { consumer } \\
\text { behaviour }\end{array}$ & 0.759 & 0.448 & 0.500 & 0.465 & 0.481 & 0.563 & 0.555 & 0.611 & 0.624 & 0.400 & 0.552 & 0.485 & 0.597 & 1 & & & \\
\hline $\begin{array}{l}\text { M. Egoistic } \\
\text { values }\end{array}$ & 0.907 & 0.285 & 0.389 & 0.477 & 0.328 & 0.479 & 0.340 & 0.331 & 0.412 & 0.251 & 0.422 & 0.399 & 0.319 & 0.413 & 1 & & \\
\hline $\begin{array}{l}\text { N. Altruistic } \\
\text { values }\end{array}$ & 0.811 & 0.550 & 0.567 & 0.802 & 0.460 & 0.703 & 0.615 & 0.475 & 0.611 & 0.185 & 0.581 & 0.655 & 0.361 & 0.474 & 0.468 & 1 & \\
\hline $\begin{array}{l}\text { O. Biospheric } \\
\text { values }\end{array}$ & 0.855 & 0.323 & 0.454 & 0.435 & 0.336 & 0.469 & 0.436 & 0.407 & 0.518 & 0.283 & 0.479 & 0.430 & 0.364 & 0.483 & 0.569 & 0.554 & 1 \\
\hline P. Religiosity & 0.839 & 0.497 & 0.520 & 0.690 & 0.407 & 0.570 & 0.514 & 0.439 & 0.508 & 0.192 & 0.488 & 0.567 & 0.383 & 0.440 & 0.486 & 0.657 & 0.441 \\
\hline
\end{tabular}

Note: $\mathrm{HTMT}_{0.85}$ ratios are all significant at $p<0.05 ; \sqrt{ } \mathrm{AVEs}=$ square root of AVEs.

intentions $=0.072, \mathrm{CI} s=-0.006-0.151)$. The association of perceived behavioural control with eco-social conservation intention however is positive and statistically significant $\left(\mathrm{H} 7_{\mathrm{c}}\right.$ : $\left.\beta_{\text {eco-social conservation intentions }}=0.142, \mathrm{CIs}=0.078-0.207\right)$. The results lead us to reject hypotheses $\mathrm{H} 7_{\mathrm{a}}$ and $\mathrm{H} 7_{\mathrm{b}}$ while accept $\mathrm{H} 7_{c}$. 
TABle 5: Estimates of direct effects.

\begin{tabular}{|c|c|c|c|c|c|c|c|c|c|c|c|c|c|c|}
\hline \multirow[b]{2}{*}{ Relationship } & \multicolumn{7}{|c|}{ Model $1_{\mathrm{a}}$ : original TPB model $(\mathrm{SRMR}=0.035)$} & \multicolumn{7}{|c|}{ Model $1_{\mathrm{b}}$ : extended TPB model $(\mathrm{SRMR}=0.031)$} \\
\hline & $\beta$ & SD & $\begin{array}{c}t- \\
\text { value }\end{array}$ & $R^{2}$ & $\begin{array}{l}95 \% \\
\text { CI LL }\end{array}$ & $\begin{array}{c}95 \% \\
\mathrm{CI} \\
\mathrm{UL} \\
\end{array}$ & $f^{2}$ & $\beta$ & $\mathrm{SD}$ & $\begin{array}{c}t- \\
\text { value }\end{array}$ & $R^{2}$ & $\begin{array}{l}95 \% \\
\text { CI LL }\end{array}$ & $\begin{array}{l}95 \% \\
\text { CI LL }\end{array}$ & $f^{2}$ \\
\hline $\begin{array}{l}\text { Behavioural } \\
\text { beliefs } \longrightarrow \text { attitude } \\
\text { towards behaviour }\end{array}$ & 0.446 & 0.026 & 17.209 & & 0.392 & 0.494 & $0.249^{* *}$ & 0.171 & 0.028 & 6.117 & & 0.114 & 0.228 & $0.037^{* *}$ \\
\hline 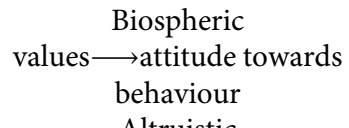 & NT & NT & NT & 0.267 & NT & NT & NT & 0.041 & 0.031 & 1.325 & 0.430 & -0.022 & 0.100 & $0.002^{\mathrm{ns}}$ \\
\hline values $\underset{\text { behaviour }}{\longrightarrow}$ attitude towards & NT & NT & NT & & NT & NT & NT & 0.316 & 0.032 & 9.948 & & 0.251 & 0.376 & $0.098^{* *}$ \\
\hline $\begin{array}{l}\text { Egoistic values } \longrightarrow \text { attitude } \\
\text { towards behaviour }\end{array}$ & NT & NT & NT & & NT & NT & NT & 0.126 & 0.029 & 4.310 & & 0.072 & 0.182 & $0.019^{*}$ \\
\hline $\begin{array}{l}\text { Normative injunctive } \\
\text { beliefs } \longrightarrow \text { subjective } \\
\text { injunctive norms }\end{array}$ & 0.617 & 0.019 & 32.545 & 0.381 & 0.578 & 0.653 & $0.616^{*}$ & 0.617 & 0.018 & 33.886 & 0.381 & 0.578 & 0.651 & $0.616^{* *}$ \\
\hline $\begin{array}{l}\text { Normative descriptive } \\
\text { beliefs } \longrightarrow \text { subjective } \\
\text { descriptive norms } \\
\text { Control }\end{array}$ & 0.438 & 0.027 & 16.307 & 0.192 & 0.382 & 0.488 & $0.238^{* *}$ & 0.438 & 0.025 & 17.353 & 0.192 & 0.380 & 0.484 & $0.238^{* *}$ \\
\hline $\begin{array}{c}\text { beliefs } \longrightarrow \text { perceived } \\
\text { behavioural control } \\
\text { Attitude towards }\end{array}$ & 0.330 & 0.026 & 12.458 & 0.222 & 0.278 & 0.383 & $0.141^{* *}$ & 0.471 & 0.023 & 20.537 & 0.222 & 0.427 & 0.516 & $0.285^{* *}$ \\
\hline $\begin{array}{l}\text { behaviour } \longrightarrow \text { eco-social } \\
\text { purchase intention }\end{array}$ & 0.095 & 0.036 & 2.609 & & 0.025 & 0.167 & $0.006^{\mathrm{ns}}$ & 0.079 & 0.040 & 2.010 & & 0.013 & 0.163 & $0.004^{\mathrm{ns}}$ \\
\hline $\begin{array}{l}\text { Subjective injunctive } \\
\text { norms } \longrightarrow \text { eco-social } \\
\text { purchase intention }\end{array}$ & 0.042 & 0.032 & 1.290 & & -0.022 & 0.109 & $0.001^{\mathrm{ns}}$ & 0.041 & 0.033 & 1.229 & & -0.026 & 0.105 & $0.001^{\mathrm{ns}}$ \\
\hline $\begin{array}{l}\text { Subjective descriptive } \\
\text { norms } \longrightarrow \text { eco-social } \\
\text { purchase intention }\end{array}$ & 0.245 & 0.034 & 7.248 & & 0.179 & 0.312 & $0.044^{* *}$ & 0.230 & 0.034 & 6.783 & & 0.164 & 0.296 & $0.040^{* *}$ \\
\hline $\begin{array}{l}\text { Perceived behavioural } \\
\text { control } \longrightarrow \text { eco-social } \\
\text { purchase intention }\end{array}$ & 0.005 & 0.039 & 0.121 & 0.106 & -0.077 & 0.074 & $0.000^{\mathrm{ns}}$ & -0.020 & 0.042 & 0.482 & 0.127 & -0.095 & 0.063 & $0.000^{\mathrm{ns}}$ \\
\hline $\begin{array}{l}\text { Biospheric values } \longrightarrow \text { eco- } \\
\text { social purchase intention }\end{array}$ & NT & NT & NT & & NT & NT & NT & 0.114 & 0.035 & 3.263 & & 0.044 & 0.179 & $0.010^{\mathrm{ns}}$ \\
\hline $\begin{array}{l}\text { Altruistic values } \longrightarrow \text { eco- } \\
\text { social purchase intention }\end{array}$ & NT & NT & NT & & NT & NT & NT & -0.076 & 0.035 & 2.181 & & -0.149 & 0.013 & $0.004^{\mathrm{ns}}$ \\
\hline $\begin{array}{l}\text { Egoistic values } \longrightarrow \text { eco- } \\
\text { social purchase intention } \\
\text { Attitude towards }\end{array}$ & NT & NT & NT & & NT & NT & NT & 0.090 & 0.035 & 2.542 & & 0.020 & 0.158 & $0.006^{\mathrm{ns}}$ \\
\hline $\begin{array}{l}\text { behaviour } \longrightarrow \text { eco-social } \\
\text { use intention }\end{array}$ & 0.260 & 0.031 & 8.433 & & 0.200 & 0.319 & $0.068^{* *}$ & 0.167 & 0.031 & 5.449 & & 0.111 & 0.230 & $0.026^{* *}$ \\
\hline $\begin{array}{l}\text { Subjective injunctive } \\
\text { norms } \underset{\text { intention }}{\longrightarrow} \text { eco-social use }\end{array}$ & 0.211 & 0.031 & 6.612 & & 0.153 & 0.275 & $0.044^{* *}$ & 0.154 & 0.034 & 4.594 & & 0.087 & 0.218 & $0.023^{*}$ \\
\hline $\begin{array}{l}\text { Subjective descriptive } \\
\text { norms } \longrightarrow \text { eco-social use } \\
\text { intention }\end{array}$ & 0.168 & 0.029 & 5.750 & & 0.111 & 0.223 & $0.029^{*}$ & 0.155 & 0.031 & 5.086 & & 0.098 & 0.212 & $0.026^{*}$ \\
\hline $\begin{array}{l}\text { Perceived behavioural } \\
\text { control } \longrightarrow \text { eco-social use } \\
\text { intention }\end{array}$ & 0.124 & 0.035 & 3.506 & 0.364 & 0.052 & 0.189 & $0.013^{\mathrm{ns}}$ & 0.072 & 0.040 & 1.823 & 0.399 & -0.006 & 0.151 & $0.004^{\mathrm{ns}}$ \\
\hline $\begin{array}{l}\text { Biospheric values } \longrightarrow \text { eco- } \\
\text { social use intention }\end{array}$ & NT & NT & NT & & NT & NT & NT & 0.011 & 0.031 & 0.360 & & -0.048 & 0.071 & $0.000^{\mathrm{ns}}$ \\
\hline $\begin{array}{l}\text { Altruistic values } \longrightarrow \text { eco- } \\
\text { social use intention }\end{array}$ & NT & NT & NT & & NT & NT & NT & 0.228 & 0.038 & 6.082 & & 0.155 & 0.302 & $0.047^{* *}$ \\
\hline $\begin{array}{l}\text { Egoistic values } \longrightarrow \text { eco- } \\
\text { social use intention }\end{array}$ & NT & NT & NT & & NT & NT & NT & 0.048 & 0.028 & 1.720 & & -0.005 & 0.104 & $0.003^{\mathrm{ns}}$ \\
\hline
\end{tabular}


TABLE 5: Continued.

\begin{tabular}{|c|c|c|c|c|c|c|c|c|c|c|c|c|c|c|}
\hline \multirow[b]{2}{*}{ Relationship } & \multicolumn{7}{|c|}{ Model $1_{\mathrm{a}}$ : original TPB model $(\mathrm{SRMR}=0.035)$} & \multicolumn{7}{|c|}{ Model $1_{\mathrm{b}}$ : extended TPB model $(\mathrm{SRMR}=0.031)$} \\
\hline & $\beta$ & $\mathrm{SD}$ & $\begin{array}{c}t- \\
\text { value }\end{array}$ & $R^{2}$ & $\begin{array}{l}95 \% \\
\text { CI LL }\end{array}$ & $\begin{array}{c}95 \% \\
\text { CI } \\
\text { UL } \\
\end{array}$ & $f^{2}$ & $\beta$ & SD & $\begin{array}{c}t- \\
\text { value }\end{array}$ & $R^{2}$ & $\begin{array}{c}95 \% \\
\text { CI LL }\end{array}$ & $\begin{array}{l}95 \% \\
\text { CI LL }\end{array}$ & $f^{2}$ \\
\hline $\begin{array}{l}\text { Attitude towards } \\
\text { behaviour } \longrightarrow \text { eco-social } \\
\text { conservation intention }\end{array}$ & 0.219 & 0.028 & 7.956 & & 0.165 & 0.276 & $0.054^{* *}$ & 0.151 & 0.029 & 5.269 & & 0.099 & 0.207 & $0.023^{* *}$ \\
\hline $\begin{array}{l}\text { Subjective injunctive } \\
\text { norms } \longrightarrow \text { eco-social } \\
\text { conservation intention }\end{array}$ & 0.248 & 0.031 & 8.051 & & 0.188 & 0.308 & $0.067^{* *}$ & 0.210 & 0.033 & 6.416 & & 0.139 & 0.272 & $0.047^{* *}$ \\
\hline $\begin{array}{l}\text { Subjective descriptive } \\
\text { norms } \longrightarrow \text { eco-social } \\
\text { conservation intention }\end{array}$ & 0.164 & 0.030 & 5.414 & & 0.105 & 0.222 & $0.031^{*}$ & 0.149 & 0.029 & 5.207 & & 0.092 & 0.206 & $0.026^{* *}$ \\
\hline $\begin{array}{l}\text { Perceived behavioural } \\
\text { control } \longrightarrow \text { eco-social } \\
\text { conservation intention }\end{array}$ & 0.192 & 0.033 & 5.887 & 0.425 & 0.133 & 0.255 & $0.035^{*}$ & 0.142 & 0.033 & 4.334 & 0.449 & 0.078 & 0.207 & $0.019^{*}$ \\
\hline $\begin{array}{l}\text { Biospheric values } \longrightarrow \text { eco- } \\
\text { social conservation } \\
\text { intention }\end{array}$ & NT & NT & NT & & NT & NT & NT & 0.077 & 0.028 & 2.754 & & 0.023 & 0.132 & $0.007^{\mathrm{ns}}$ \\
\hline $\begin{array}{l}\text { Altruistic values } \longrightarrow \text { eco- } \\
\text { social conservation } \\
\text { intention }\end{array}$ & NT & NT & NT & & NT & NT & NT & 0.107 & 0.029 & 3.693 & & 0.045 & 0.160 & $0.011^{\mathrm{ns}}$ \\
\hline $\begin{array}{l}\text { Egoistic values } \longrightarrow \text { eco- } \\
\text { social conservation } \\
\text { intention }\end{array}$ & NT & NT & NT & & NT & NT & NT & 0.076 & 0.028 & 2.715 & & 0.020 & 0.133 & $0.007^{\mathrm{ns}}$ \\
\hline $\begin{array}{l}\text { Religiosity } \longrightarrow \text { attitude } \\
\text { towards behaviour }\end{array}$ & NT & NT & NT & & NT & NT & NT & 0.117 & 0.035 & 3.332 & & 0.045 & 0.185 & $0.012^{\mathrm{ns}}$ \\
\hline
\end{tabular}

Note: ${ }^{* *} p<0.01$ and ${ }^{*} p<0.05 ; \mathrm{CI}=$ bias-corrected confidence interval; $\mathrm{LL}=$ lower level; $\mathrm{UL}=$ upper level; $\mathrm{SD}=$ standard deviation; ns $=$ not significant; $\mathrm{NT}=$ not tested. Effect size impact indicators are according to Cohen 93, 97, 96 and Chin [94, 98, 97]; $f^{2}$ values: 0.35 (large), 0.15 (medium), and 0.02 (small); $Q^{2}=(1-S S E / S S O) . Q^{2}$ values: eco-social Use Intentions=0.256; Eco-social conservation intentions=0.342; eco-social purchase intentions=0.087; $\mathrm{ESCCB}=0.239$.

TABLE 6: Summary of results of hypotheses.

\begin{tabular}{|c|c|c|c|}
\hline Hypotheses & Estimate & $t$-value & Result \\
\hline $\begin{array}{l}\text { H1: behavioural beliefs are positively associated with attitude towards eco-socially conscious } \\
\text { consumer behaviour related to AFVs }\end{array}$ & 0.171 & $6.117^{* *}$ & Supported \\
\hline $\mathbf{H} 2_{\mathrm{a}}$ : normative injunctive beliefs are positively associated with subjective injunctive norms & 0.617 & $33.886^{* *}$ & Supported \\
\hline H2b: normative descriptive beliefs are positively associated with subjective descriptive norms & 0.438 & & \\
\hline rol beliefs are positively associated with perceived behavioural control & 0.471 & $.537^{* *}$ & pported \\
\hline H4a : subjective descriptive norms positively lead to eco-social purchase intentions related to AFVs & 0.230 & 6.78 & Supported \\
\hline $\mathbf{H 4}_{\mathbf{b}}$ : subjective descriptive norms positively lead to eco-social use intentions related to AFVs & 0.155 & & Supported \\
\hline $\mathbf{H 4}_{\mathbf{c}}$ : subjective descriptive norms positively lead to eco-social conservation intentions related to AFVs & 0.149 & $5.207^{* *}$ & Supported \\
\hline H5 $\mathbf{a}_{\mathbf{a}}$ : subjective injunctive norms positively lead to eco-social purchase intentions related to AFVs & 0.041 & $1.229^{\mathrm{ns}}$ & $\begin{array}{l}\text { Not } \\
\text { supported }\end{array}$ \\
\hline $\mathbf{H 5}_{\mathbf{b}}$ : subjective injunctive norms positively lead to eco-social use intentions related to AFVs & 0.154 & $4.594^{*}$ & Supported \\
\hline elated to AFVs & 0.210 & & ted \\
\hline $\mathbf{H 6}_{\mathbf{a}}$ : attitudes towards behaviour positively lead to eco-social purchase intentions related to AFVs & 0.079 & & Supported \\
\hline $\mathbf{H 6}_{\mathbf{b}}$ : attitudes towards behaviour positively lead to eco-social use intentions related to AFVs & 0.167 & $5.449^{* *}$ & \\
\hline H6$_{\mathbf{c}}$ : attitudes towards behaviour positively lead eco-social conservation intentions related to AFVs & 0.151 & $5.269^{* *}$ & \\
\hline H7a: perceived behavioural control positively leads to eco-social purchase intentions related to AFVs & -0.020 & $0.482^{\mathrm{ns}}$ & $\begin{array}{l}\text { Not } \\
\text { supported }\end{array}$ \\
\hline H7b: perceived behavioural control positively leads to eco-social use intentions related $t$ & 0.072 & $1.823^{\mathrm{ns}}$ & $\begin{array}{c}\text { Not } \\
\text { supported }\end{array}$ \\
\hline $\begin{array}{l}\text { H7c: perceived behavioural control positively leads to eco-social conservation intentions related to } \\
\text { AFVs }\end{array}$ & 0.142 & $4.334^{*}$ & Supported \\
\hline $\begin{array}{l}\text { H8a: altruistic values are positively associated with attitude towards eco-socially conscious consumer } \\
\text { behaviour related to AFVs }\end{array}$ & 0.316 & $9.948^{* *}$ & Supported \\
\hline $\begin{array}{l}\text { H8b: egoistic values are positively associated with attitude towards eco-socially conscious consumer } \\
\text { behaviour related to AFVs }\end{array}$ & 0.126 & & \\
\hline
\end{tabular}


TABLE 6: Continued.

\begin{tabular}{|c|c|c|c|}
\hline Hypotheses & Estimate & $t$-value & Result \\
\hline $\begin{array}{l}\text { H8c: biospheric values are positively associated with attitude towards eco-socially conscious consumer } \\
\text { behaviour related to AFVs }\end{array}$ & 0.041 & $1.325^{\mathrm{ns}}$ & $\begin{array}{l}\text { Not } \\
\text { supported }\end{array}$ \\
\hline H9a: altruistic values are positively associated with eco-social purchase intentions related to AFVs & -0.076 & $2.181^{\mathrm{ns}}$ & $\begin{array}{l}\text { Not } \\
\text { supported }\end{array}$ \\
\hline H9b: altruistic values are positively associated with eco-social use intentions related to AFVs & 0.228 & $6.082^{* *}$ & Supported \\
\hline H9c: altruistic values are positively associated with eco-social conservation intentions related to AFVs & 0.107 & $3.693^{*}$ & Supported \\
\hline H10a: egoistic values are positively associated with eco-social purchase intentions related to AFVs & -0.076 & $2.181^{*}$ & Supported \\
\hline H10b: egoistic values are positively associated with eco-social use intentions related to AFVs & 0.048 & $1.720^{\mathrm{ns}}$ & $\begin{array}{l}\text { Not } \\
\text { supported }\end{array}$ \\
\hline H10c: egoistic values are positively associated with eco-social conservation intentions related to AFVs & 0.076 & $2.715^{*}$ & Supported \\
\hline H11a: biospheric values are positively associated with eco-social purchase intentions related to AFVs & 0.114 & $3.263^{*}$ & Supported \\
\hline H11b: biospheric values are positively associated with eco-social use intentions related to AFVs & 0.011 & $0.360^{\mathrm{ns}}$ & $\begin{array}{l}\text { Not } \\
\text { supported }\end{array}$ \\
\hline $\begin{array}{l}\text { H11c: biospheric values are positively associated with eco-social conservation intentions related to } \\
\text { AFVs }\end{array}$ & 0.077 & $2.754^{*}$ & Supported \\
\hline $\begin{array}{l}\text { H12: religiosity is positively associated with attitude towards eco-socially conscious consumer } \\
\text { behaviour related to AFVs }\end{array}$ & 0.117 & $3.332^{*}$ & Supported \\
\hline
\end{tabular}

Note: ${ }^{* *} p<0.01$ and ${ }^{*} p<0.05$.

The hypotheses related to the extended part of the TPB model present mixed results. For instance, altruistic and egoistic values are found positively associated with attitude towards eco-socially conscious consumer behaviour related to AFVs $\left(\mathrm{H} 8_{\mathrm{a}}: \beta_{\text {altruistic values }}=0.316, \mathrm{CIs}=0.251-0.376 ; \mathrm{H}_{\mathrm{b}}\right.$ : $\beta_{\text {egoistic values }}=0.126$, CIs $\left.=0.072-0.182\right)$ while biospheric values have no such relationship $\left(\mathrm{H}_{\mathrm{c}}\right.$ : $\beta_{\text {biospheric val- }}$ ues $=0.041$, CIs $=-0.022-0.100)$ leading us to accept hypotheses $\mathrm{H} 8_{\mathrm{a}}$ and $\mathrm{H} 8_{\mathrm{b}}$ while reject $\mathrm{H} 8_{\mathrm{c}}$. A similar pattern of results is evident for the relationship between altruistic, egoistic, and biospheric values and the three facets of ecosocial behavioural intentions related to AFVs.

The altruistic values are found to have no significant association with eco-social purchase intentions $\left(\mathrm{H} 9_{\mathrm{a}}\right.$ : $\beta_{\text {eco- }}$ social purchase intentions $=-0.076, \mathrm{CIs}=-0.149-0.013$ ) but are positively associated with eco-social use $\left(\mathrm{H} 9_{\mathrm{b}}\right.$ : $\beta_{\text {eco-social use }}$ intentions $=0.228$, CIs $=0.155-0.302)$ and eco-social conservation intentions $\left(\mathrm{H} 9_{\mathrm{c}}: \beta_{\mathrm{eco}-\text { social conservation intentions }}=0.107\right.$, CIs $=0.045-0.160)$. Similarly, egoistic values are found to have no significant association with eco-social use intentions $\left(\mathrm{H} 10_{\mathrm{b}}: \beta_{\text {eco-social use intentions }}=0.048, \mathrm{CIs}=-0.005-0.014\right)$ but are positively associated with eco-social purchase $\left(\mathrm{H} 10_{\mathrm{a}}\right.$ : $\left.\beta_{\text {eco-social purchase intentions }}=0.090, \mathrm{CIs}=0.020-0.158\right)$ and eco-social conservation intentions $\left(\mathrm{H} 10_{\mathrm{c}}\right.$ : $\beta_{\text {eco-social conserva- }}$ tion intentions $=0.076, \mathrm{CIs}=0.020-0.133$ ). The biospheric values are found to have no significant association with ecosocial use intentions $\left(\mathrm{H}_{1} 1_{\mathrm{b}}\right.$ : $\beta_{\text {eco-social use intentions }}=0.011$, CIs $=-0.048-0.071)$ but are positively associated with ecosocial purchase $\left(\mathrm{H} 11_{\mathrm{a}}: \beta_{\text {eco-social }}\right.$ purchase intentions $=0.114$, CIs $=0.044-0.179)$ and eco-social conservation intentions $\left(\mathrm{H} 11_{\mathrm{c}}\right.$ : $\quad \beta_{\text {eco-social }} \quad$ conservation $\quad$ intentions $=0.077$, CIs $=0.023-0.132)$. Finally, the study results revealed that religiosity is positively associated with attitude towards ecosocially conscious consumer behaviour related to AFVs (H12: $\beta=0.117$, CIs $=0.045-0.185)$.

4.3.1. Predictive Power Assessment of the Model. Apart from the structural model evaluation, this study also carried out a predictive power assessment of the proposed extended model of TPB. While $R^{2}$ measures of the endogenous constructs reflect the model fit and explanatory power with the sample at hand, such measures fail to reflect on the model's out-of-sample predictive power [95]. This study applied PLS-predict procedures to assess the path models out-of-sample predictive power following the guidelines of Shmueli, Ray, Velasquez Estrada, and Chatla [96]. As the conceptualised path model of this study included three primary endogenous constructs, we compared the root mean squared error (RMSE) value of the linear regression model (LM) with the PLS-SEM model for each indicator of the three endogenous constructs. The results presented in Table 7 reveal that RMSE values of all indicators of the PLSSEM model are lower than the RMSE values of LM; hence, the model has high predictive power [96].

\section{Discussion and Implications}

The integrated model's conceptual proposal shows a link between value orientations (the construct of the VBN theory) and attitude towards behaviour (the construct of the TPB). The estimates confirm that egoistic and altruistic values are associated with attitudes towards behaviour. This means that the individuals who have induced their self-interest associated with a particular pro-environmental behaviour and have the nature of helping others tend to develop a positive attitude towards ESCCB. However, contrary to the literature, biospheric values were found to have no relation with attitude towards behaviour. There is a stream of research that explains this exception. Although concern for the environment is highly relevant in eliciting positive sentiments towards environment-friendly products in case of low involvement products, for high-involvement decisions, this often fails to generate favourable responses [10].

Comparison of the two models (original TPB model and the extended TPB model) shows that the extended model reflects better model fit indices and explanatory power than 
TABLE 7: Predictive validity score from PLS-predict module.

\begin{tabular}{|c|c|c|c|c|c|c|c|c|c|}
\hline \multirow{2}{*}{ Manifest variables of the endogenous constructs } & \multicolumn{3}{|c|}{ LM } & \multicolumn{3}{|c|}{ PLS-SEM } & \multicolumn{3}{|c|}{ PLS-LM } \\
\hline & RMSE & MAE & $Q^{2}$-predict & RMSE & MAE & $Q^{2}$ & RMSE & MAE & $Q^{2}$ \\
\hline ESCCBCONINT1 & 1.515 & 1.214 & 0.226 & 1.296 & 1.001 & 0.434 & -0.219 & -0.213 & 0.208 \\
\hline ESCCBCONINT2 & 1.393 & 1.076 & 0.233 & 1.199 & 0.912 & 0.433 & -0.194 & -0.164 & 0.200 \\
\hline ESCCBCONINT3 & 1.337 & 1.054 & 0.247 & 1.184 & 0.927 & 0.410 & -0.153 & -0.127 & 0.163 \\
\hline ESCCBUSEINT1 & 1.667 & 1.259 & -0.070 & 1.297 & 0.994 & 0.353 & -0.370 & -0.265 & 0.423 \\
\hline ESCCBUSEINT2 & 1.621 & 1.213 & -0.021 & 1.286 & 0.978 & 0.357 & -0.335 & -0.235 & 0.378 \\
\hline ESCCBUSEINT3 & 1.538 & 1.135 & -0.022 & 1.306 & 1.006 & 0.263 & -0.232 & -0.129 & 0.285 \\
\hline ESCCBPURINT1 & 1.871 & 1.480 & -0.275 & 1.462 & 1.179 & 0.221 & -0.409 & -0.301 & 0.496 \\
\hline ESCCBPURINT2 & 2.021 & 1.627 & -0.417 & 1.540 & 1.243 & 0.177 & -0.481 & -0.384 & 0.594 \\
\hline ESCCBPURINT3 & 2.119 & 1.733 & -0.437 & 1.595 & 1.314 & 0.186 & -0.524 & -0.419 & 0.623 \\
\hline \multicolumn{7}{|c|}{ Eco-social use intentions } & 0.199 & & \\
\hline \multirow[t]{2}{*}{ Latent variable $(\mathrm{LV})$ prediction $\left(Q^{2}\right.$-predict $)$} & \multicolumn{3}{|c|}{$\begin{array}{c}\text { Eco-social conservation } \\
\text { intentions }\end{array}$} & & & & 0.126 & & \\
\hline & \multicolumn{3}{|c|}{$\begin{array}{l}\text { Eco-social purchase } \\
\text { intentions }\end{array}$} & & & & -0.521 & & \\
\hline
\end{tabular}

Note: ESCCBCONINT1, ESCCBCONINT2, and ESCCBCONINT3: Eco-social conservation intention indicators; ESCCBUSEINT1, ESCCBUSEINT2, and ESCCBUSEINT3: eco-social use intention indicators; ESCCBPURINT1, ESCCBPURINT2, and ESCCBPURINT3: eco-social purchase intention indicators; $\mathrm{RMSE}=$ root mean square error; $\mathrm{LM}=$ linear regression model; $\mathrm{MAE}=$ mean absolute error; predictive validity exists when the PLS-LM columns are negative for errors (RMSE and MAE) and positive for $Q^{2}$.

the original models. The explanatory power of the extended model for all endogenous variables is greater than that of the original model (eco-social purchase intentions: $R^{2}$ extended model $=0.127$ vs $R^{2}$ original model $=0.106$; eco-social use intentions: $R_{\text {extended model }}^{2}=0.399$ vs $R^{2}$ original model $=0.364$; ecosocial conservation intentions: $R^{2}$ extended model $=0.449$ vs $R^{2}$ original model $=0.425$; attitudes towards behaviour: $R^{2}$ extended model $=0.430$ vs $R^{2}$ original model $=0.267$ ).

The core constructs of the TPB model include normative beliefs (injunctive and descriptive), beliefs towards behaviour, and control beliefs. These beliefs link directly with their corresponding attitude set (subjective norms, attitude towards behaviour, and perceived behavioural control), leading to ecosocial purchase, use, and conservation intentions. Results reported in Table 6 show that, as proposed, the individuals' beliefs are positively associated with attitude towards behaviours, subject norms, and perceived behavioural control. It is, however, evident that normative beliefs (injunctive and descriptive) have a stronger association with their respective causal chain constructs (injunctive and descriptive norms) than behavioural beliefs. This suggests that normative beliefs are stronger triggers of eco-social intentions at the initial level of the causal array of the TPB and that individuals who believe that important others are involved in eco-social behaviours and require the same from individuals are likely to develop positive subjective norms. The control beliefs are the second most important set of beliefs in terms of strength of association with respective attitude, i.e., perceived behavioural control, followed by association of behavioural beliefs with attitude towards behaviour. However, the results showed that religiosity is significantly associated with attitude towards behaviour but is the weakest factor in terms of the magnitude of association. This is somehow surprising for a collectivist religious society. However, the recent wave of liberalism and departure from dogmatic religious following has started a debate in Pakistani society about the rational justification of religious teachings instead of blind faith. This has increased tolerance for conflicting beliefs, and behaviours are more often driven primarily through the lenses of self-interest. Apart from consistency with some literature on religiosity and pro-environmental behaviours $[97,98]$, this evidence also is consistent with findings from a recent study conducted in China [99].

Further analysis shows that attitude towards eco-socially conscious consumer behaviour is positively associated with eco-social purchase use and conservation intentions; the link is fragile between attitude towards behaviour and eco-social purchase intentions. Furthermore, in the causal chain, it is evident that the individuals who are influenced by important others (subjective injunctive norms) engage in eco-social intentions from use and conservation intentions but not purchase intentions. However, if individuals find important others to be actually involved in eco-socially conscious consumer behaviour (subjective descriptive norms), they will develop eco-social purchase, use, and conservation intentions. Contrarily, perceived behavioural intention was controlled positively to conservation intentions but not to purchase and use intentions.

5.1. Theoretical Implications. First, the model informs that religiosity is an important construct that can develop positive attitudes towards environmental causes or pro-environmental products/behaviours. Such linkage supports the assertion that religious beliefs can be associated with proenvironmental or prosocial attitudes at the individual level. Moving further on, the integrated model suggests that environmental-specific values have a powerful association with the attitude towards ESCCB, which is not only theoretically plausible but also a very useful finding for future studies. Initially, the traditional values and lifestyle inventory was considered in some past studies $[100,101]$, and the original theoretical proposal of the TPB [34] was found to be associated with beliefs. However, the integrated model 
TABLE 8: Estimates of total indirect effects.

\begin{tabular}{|c|c|c|c|c|c|c|c|c|c|c|}
\hline \multirow[b]{2}{*}{ Relationship } & \multicolumn{5}{|c|}{ Model $1_{\mathrm{a}}$ : original TPB model } & \multicolumn{5}{|c|}{ Model $1_{\mathrm{b}}$ : extended TPB model } \\
\hline & $\beta$ & $\mathrm{SD}$ & $\begin{array}{c}t- \\
\text { value }\end{array}$ & $\begin{array}{l}95 \% \mathrm{CI} \\
\mathrm{LL}\end{array}$ & $\begin{array}{l}95 \% \text { CI } \\
\text { UL }\end{array}$ & $\beta$ & $\mathrm{SD}$ & $\begin{array}{c}t- \\
\text { value }\end{array}$ & $\begin{array}{l}95 \% \mathrm{CI} \\
\quad \mathrm{LL}\end{array}$ & $\begin{array}{l}95 \% \mathrm{C} \\
\mathrm{UL}\end{array}$ \\
\hline $\begin{array}{l}\text { Behavioural beliefs } \longrightarrow \text { eco-social purchase } \\
\text { intentions }\end{array}$ & 0.042 & 0.017 & 2.541 & 0.011 & 0.076 & 0.018 & 0.007 & 2.451 & 0.006 & 0.034 \\
\hline $\begin{array}{l}\text { Normative injunctive belief } \longrightarrow \text { eco-social } \\
\text { purchase intentions }\end{array}$ & 0.026 & 0.020 & 1.282 & -0.013 & 0.067 & 0.026 & 0.020 & 1.290 & -0.010 & 0.068 \\
\hline $\begin{array}{l}\text { Normative descriptive belief } \longrightarrow \text { eco-social } \\
\text { purchase intentions }\end{array}$ & 0.107 & 0.016 & 6.837 & 0.079 & 0.140 & 0.108 & 0.015 & 7.084 & 0.076 & 0.136 \\
\hline $\begin{array}{l}\text { Control beliefs } \longrightarrow \text { eco-social purchase } \\
\text { intentions }\end{array}$ & 0.002 & 0.013 & 0.121 & -0.026 & 0.025 & 0.002 & 0.013 & 0.116 & -0.025 & 0.028 \\
\hline Behavioural beliefs $\longrightarrow$ eco-social use intentions & 0.116 & 0.016 & 7.125 & 0.088 & 0.152 & 0.050 & 0.009 & 5.252 & 0.033 & 0.070 \\
\hline $\begin{array}{l}\text { Normative injunctive belief } \longrightarrow \text { eco-social use } \\
\text { intentions }\end{array}$ & 0.131 & 0.021 & 6.128 & 0.092 & 0.175 & 0.130 & 0.021 & 6.111 & 0.089 & 0.172 \\
\hline $\begin{array}{l}\text { Normative descriptive belief } \longrightarrow \text { eco-social use } \\
\text { intentions }\end{array}$ & 0.074 & 0.014 & 5.252 & 0.047 & 0.101 & 0.074 & 0.014 & 5.224 & 0.047 & 0.101 \\
\hline Control beliefs $\longrightarrow$ eco-social use intentions & 0.041 & 0.012 & 3.434 & 0.018 & 0.063 & 0.041 & 0.012 & 3.301 & 0.015 & 0.065 \\
\hline $\begin{array}{l}\text { Behavioural beliefs } \longrightarrow \text { eco-social conservation } \\
\text { intentions }\end{array}$ & 0.098 & 0.014 & 6.840 & 0.073 & 0.130 & 0.042 & 0.008 & 4.996 & 0.027 & 0.060 \\
\hline $\begin{array}{l}\text { Normative injunctive belief } \longrightarrow \text { eco-social } \\
\text { conservation intentions }\end{array}$ & 0.153 & 0.020 & 7.522 & 0.115 & 0.193 & 0.153 & 0.020 & 7.653 & 0.113 & 0.190 \\
\hline $\begin{array}{l}\text { Normative descriptive belief } \longrightarrow \text { eco-social } \\
\text { conservation intentions }\end{array}$ & 0.072 & 0.014 & 5.068 & 0.046 & 0.102 & 0.072 & 0.014 & 5.290 & 0.047 & 0.099 \\
\hline $\begin{array}{l}\text { Control beliefs } \longrightarrow \text { eco-social conservation } \\
\text { intentions }\end{array}$ & 0.063 & 0.012 & 5.138 & 0.042 & 0.091 & 0.063 & 0.013 & 5.019 & 0.040 & 0.089 \\
\hline $\begin{array}{l}\text { Altruistic values } \longrightarrow \text { eco-social purchase } \\
\text { intentions }\end{array}$ & NT & NT & NT & NT & NT & 0.038 & 0.015 & 2.616 & 0.012 & 0.067 \\
\hline Egoistic values $\longrightarrow$ eco-social purchase intentions & NT & NT & NT & NT & NT & 0.015 & 0.006 & 2.436 & 0.005 & 0.029 \\
\hline $\begin{array}{l}\text { Biospheric values } \longrightarrow \text { eco-social purchase } \\
\text { intentions }\end{array}$ & NT & NT & NT & NT & NT & 0.007 & 0.004 & 1.670 & 0.001 & 0.018 \\
\hline Altruistic values $\longrightarrow$ eco-social use intentions & NT & NT & NT & NT & NT & 0.105 & 0.015 & 6.839 & 0.077 & 0.137 \\
\hline Egoistic values $\longrightarrow$ eco-social use intentions & NT & NT & NT & NT & NT & 0.040 & 0.009 & 4.674 & 0.025 & 0.058 \\
\hline Biospheric values $\longrightarrow$ eco-social use intentions & NT & NT & NT & NT & NT & 0.019 & 0.008 & 2.354 & 0.004 & 0.036 \\
\hline $\begin{array}{l}\text { Altruistic values } \longrightarrow \text { eco-social conservation } \\
\text { intentions }\end{array}$ & NT & NT & NT & NT & NT & 0.088 & 0.014 & 6.518 & 0.064 & 0.117 \\
\hline $\begin{array}{l}\text { Egoistic values } \longrightarrow \text { eco-social conservation } \\
\text { intentions }\end{array}$ & NT & NT & NT & NT & NT & 0.034 & 0.008 & 4.234 & 0.020 & 0.051 \\
\hline $\begin{array}{l}\text { Biospheric values } \longrightarrow \text { eco-social conservation } \\
\text { intentions }\end{array}$ & NT & NT & NT & NT & NT & 0.016 & 0.007 & 2.219 & 0.003 & 0.032 \\
\hline
\end{tabular}

Note: $\mathrm{CI}=$ bias-corrected confidence interval; $\mathrm{LL}=$ lower level; $\mathrm{UL}=$ upper level; $\mathrm{SD}=$ standard deviation; $\mathrm{NT}=$ not tested.

presented in this thesis argues that specific environmental values are more strongly associated with attitude towards ESCCB.

The proposal and validation of the extended TPB models in this thesis contribute to the relevant literature in several ways. First, the application of the TPB model in the context of an emerging economy and its receiving full support testifies that the TPB proposal is equally applicable in the emerging economies as well and can be applied to various other cultural contexts of similar nature to Pakistan. Second, the behavioural context of eco-social purchase, use, and conservation intentions related to AFVs is another unique contribution to the TPB model. While curtailment and efficiency behaviours have been validated in some past studies in isolation $[8,102]$, the current extended TPB model is the first of its kind to propose an integrated endogenous measure, including curtailment, efficiency, and eco-innovation adoption behaviours. Third, the divergent analysis of injunctive and descriptive norms instead of combined subjective norms construct has not been very common in the extant literature of the TPB [103-106]. Finally, in response to many calls in the literature for providing out-of-sample predictive power analysis of theoretical models, this study employed PLS-predict procedure to verify predictive validity and power of the extended TPB model. The results testified that the extended TPB model holds substantial out-ofsample predictive power.

5.2. Practical Implications. There are multiple guidelines for policymakers and marketers of the automobile industry based on the integrated model results. First, the concept of religiosity may be utilised to promote AFVs. Careful attention will be required to understand the specific religious beliefs associated with AFVs and the development of messages that do not overemphasise religious beliefs, as this 
is expected to result in a psychological defence mechanism. In addition, the results related to the impact of religiosity on attitude need to be considered with caution as the effect size of the said relationship is not significant (see Table 5). The attitude towards AFVs can be favourably moulded with the help of promoting environmental values. Again, the communication messages featuring the benefits of using public transport, conserving fuel, and advantages of AFVs to personal and others' health and environment can help to develop a positive attitude towards purchase, use, and conservation intentions. Finally, to trigger the pro-environmental personal norms, an important aspect can be providing evidence of others being involved in actual behaviours being promoted, thus persuading the individuals as well to support AFVs.

The estimates of the extended model of the TPB provide several guidelines for marketers and policymakers. First, building on Fishbein and Ajzen [34] original guidelines, this study suggests developing an appropriate persuasive message aimed at changing the personal car use behaviours of customers in the context of Pakistani culture. The TPB model tested here clearly shows that the eco-social conservation, purchase, and use intentions are supported through the causal chain process of the TPB constructs and appropriate intervention may be designed and implemented to promote sustainable transport choice behaviours. For instance, results clearly show that the subjective injunctive and descriptive norms are associated with eco-social conservation intentions, so communication messages targeted to promote conservation-related behaviours might feature endorsement of opinion leaders that they are also involved in conservation-related behaviours. Interestingly, the highinvolvement behaviour of eco-social purchase is only supported by subjective descriptive norms that clearly guide using actual customers as product (AFVs) ambassadors in an integrated marketing communication to promote AFVs. Similarly, a positive attitude towards behaviour and a sense of perceived behavioural control may also be evoked to facilitate customers' engagement in conservation-related behaviours. As a fundamental proposition of the TPB is that triggering behaviour-specific beliefs can help to elicit specific targeted behaviours, it is crucial to understand the bases of these beliefs for the development of a useful intervention.

5.3. Limitations and Future Research Directions. As for many other studies, the extended TPB model proposed and estimated in this study also has some limitations. First, the background factors causing the formation of beliefs have not been included in the extended TPB model. Including such factors as sociographic, lifestyle, and informational factors, personality, mood, and emotions can comprehensively explain the causal chain processes of the model. Future studies may consider including these factors in the TPB model to test whether or not these have any significant contribution to prediction. Second, building on the criticism of Sniehotta et al. [20]; who emphasised that TPB may be tested in a longitudinal design, it is suggested that future studies may focus on testing the proposed extended TPB model by using a longitudinal design and by measuring revealed preferences instead of self-reports. Finally, the profile of respondents shows that the sample is clearly skewed towards youngsters (19-26 years). While the age group represents the national population of Pakistan, a more detailed exploration of preferences of other age groups is necessary to develop a holistic policy for the promotion of AFVs and eco-social behaviour related to AFVs (Table 8).

\section{Data Availability}

The statistical data used to support the findings of this study were collected for a larger project and are under license so cannot be made freely available. Requests for access to these data should be made to Dr. Saleem at muhammad.saleem@ cdu.edu.au.

\section{Disclosure}

This research article comes from a larger project by Saleem [107] (https://researchonline.jcu.edu.au/60539/1/JCU_60539_Saleem _2019_thesis.pdf).

\section{Conflicts of Interest}

The authors declare that they have no conflicts of interest.

\section{References}

[1] A. Gkargkavouzi, G. Halkos, and S. Matsiori, "Environmental behavior in a private-sphere context: integrating theories of planned behavior and value belief norm, selfidentity and habit," Resources, Conservation and Recycling, vol. 148, pp. 145-156, 2019.

[2] M. A. Saleem, L. Eagle, and D. Low, "Climate change behaviors related to purchase and use of personal cars: development and validation of eco-socially conscious consumer behavior scale," Transportation Research Part D: Transport and Environment, vol. 59, pp. 68-85, 2018.

[3] D. Liu, H. Du, F. Southworth, and S. Ma, "The influence of social-psychological factors on the intention to choose lowcarbon travel modes in Tianjin, China," Transportation Research Part A: Policy and Practice, vol. 105, pp. 42-53, 2017.

[4] M. A. Saleem, L. Eagle, and D. Low, "Market segmentation based on eco-socially conscious consumers' behavioral intentions: evidence from an emerging economy," Journal of Cleaner Production, vol. 193, pp. 14-27, 2018b.

[5] M. Chowdhury, K. Salam, and R. Tay, "Consumer preferences and policy implications for the green car market," Marketing Intelligence \& Planning, vol. 34, no. 6, pp. 810-827, 2016.

[6] R. A. Daziano and E. Chiew, "Electric vehicles rising from the dead: data needs for forecasting consumer response toward sustainable energy sources in personal transportation," Energy Policy, vol. 51, pp. 876-894, 2012.

[7] A. Mannberg, J. Jansson, T. Pettersson, R. Brännlund, and U. Lindgren, "Do tax incentives affect households' adoption of 'green' cars? A panel study of the Stockholm congestion tax," Energy Policy, vol. 74, pp. 286-299, 2014.

[8] J. Jansson, A. Marell, and A. Nordlund, "Green consumer behavior: determinants of curtailment and eco-innovation adoption," Journal of Consumer Marketing, vol. 27, no. 4, pp. 358-370, 2010. 
[9] J. Jansson, T. Pettersson, A. Mannberg, R. Brännlund, and U. Lindgren, "Adoption of alternative fuel vehicles: influence from neighbors, family and coworkers," Transportation Research Part D: Transport and Environment, vol. 54, no. Supplement C, pp. 61-73, 2017b.

[10] M. A. Saleem, L. Eagle, and D. Low, "Determinants of ecosocially conscious consumer behavior toward alternative fuel vehicles," Journal of Consumer Marketing, vol. 38, no. 2, pp. 211-228, 2021.

[11] G. Marsden and I. Docherty, "Insights on disruptions as opportunities for transport policy change," Transportation Research Part A: Policy and Practice, vol. 51, pp. 46-55, 2013.

[12] G. Marsden, C. Mullen, I. Bache, I. Bartle, and M. Flinders, "Carbon reduction and travel behaviour: discourses, disputes and contradictions in governance," Transport Policy, vol. 35, pp. 71-78, 2014.

[13] M. A. Saleem, L. Eagle, A. Yaseen, and D. Low, "The power of spirituality," Asia Pacific Journal of Marketing \& Logistics, vol. 30, no. 4, pp. 867-888, 2018c.

[14] V. Singh, V. Singh, and S. Vaibhav, "A review and simple meta-analysis of factors influencing adoption of electric vehicles," Transportation Research Part D: Transport and Environment, vol. 86, Article ID 102436, 2020.

[15] H. Choi, J. Jang, and J. Kandampully, "Application of the extended VBN theory to understand consumers' decisions about green hotels," International Journal of Hospitality Management, vol. 51, pp. 87-95, 2015.

[16] D. L. Hoeksma, M. A. Gerritzen, A. M. Lokhorst, and P. M. Poortvliet, "An extended theory of planned behavior to predict consumers' willingness to buy mobile slaughter unit meat," Meat Science, vol. 128, pp. 15-23, 2017.

[17] J. Jansson, A. Nordlund, and K. Westin, "Examining drivers of sustainable consumption: the influence of norms and opinion leadership on electric vehicle adoption in Sweden," Journal of Cleaner Production, vol. 154, no. Supplement C, pp. 176-187, 2017a.

[18] T. Okada, T. Tamaki, and S. Managi, "Effect of environmental awareness on purchase intention and satisfaction pertaining to electric vehicles in Japan," Transportation Research Part D: Transport and Environment, vol. 67, pp. 503-513, 2019.

[19] A. Yan and W. Jia, "The influence of eliciting awe on proenvironmental behavior of tourist in religious tourism," Journal of Hospitality and Tourism Management, vol. 48, pp. 55-65, 2021.

[20] F. F. Sniehotta, J. Presseau, and V. Araújo-Soares, “Time to retire the theory of planned behaviour," Health Psychology Review, vol. 8, no. 1, pp. 1-7, 2014.

[21] M. Conner, "Extending not retiring the theory of planned behaviour: a commentary on Sniehotta, Presseau and Araújo-Soares," Health Psychology Review, vol. 9, no. 2, pp. 141-145, 2015.

[22] R. E. Rhodes, "Will the new theories (and theoreticians!) please stand up? A commentary on Sniehotta, Presseau and Araújo-Soares," Health Psychology Review, vol. 9, no. 2, pp. 156-159, 2015.

[23] A. Biehl and A. Stathopoulos, "Investigating the interconnectedness of active transportation and public transit usage as a primer for Mobility-as-a-Service adoption and deployment," Journal of Transport \& Health, vol. 18, p. 100897, 2020.

[24] E. Goh, B. Ritchie, and J. Wang, "Non-compliance in national parks: an extension of the theory of planned behaviour model with pro-environmental values," Tourism Management, vol. 59, pp. 123-127, 2017.

[25] T. Wang, B. Shen, C. H. Springer, and J. Hou, "What prevents us from taking low-carbon actions? A comprehensive review of influencing factors affecting low-carbon behaviors," Energy Research \& Social Science, vol. 71, Article ID 101844, 2021.

[26] M. E. Fishbein and I. Ajzen, Belief, Attitude, Intention and Behavior: An Introduction to Theory and Research, AddisonWesley, Reading MA, USA, 1975.

[27] I. Ajzen, "The theory of planned behavior," Organizational Behavior and Human Decision Processes, vol. 50, no. 2, pp. 179-211, 1991.

[28] K. Jiang, F. Ling, Z. Feng, K. Wang, and C. Shao, "Why do drivers continue driving while fatigued? An application of the theory of planned behaviour," Transportation Research Part A: Policy and Practice, vol. 98, pp. 141-149, 2017.

[29] S.-Y. Chen, "Using the sustainable modified TAM and TPB to analyze the effects of perceived green value on loyalty to a public bike system," Transportation Research Part A: Policy and Practice, vol. 88, pp. 58-72, 2016.

[30] S. P. Lam, "Predicting intentions to conserve water from the theory of planned behavior, perceived moral obligation, and perceived water Right1," Journal of Applied Social Psychology, vol. 29, no. 5, pp. 1058-1071, 1999.

[31] S.-P. Lam, "Predicting intention to save water: theory of planned behavior, response efficacy, vulnerability, and perceived efficiency of alternative solutions," Journal of Applied Social Psychology, vol. 36, no. 11, pp. 2803-2824, 2006.

[32] N. Adnan, S. Md Nordin, M. Hadi Amini, and N. Langove, "What make consumer sign up to PHEVs? Predicting Malaysian consumer behavior in adoption of PHEVs," Transportation Research Part A: Policy and Practice, vol. 113, pp. 259-278, 2018.

[33] C. Oztekin, G. Teksöz, S. Pamuk, E. Sahin, and D. S. Kilic, "Gender perspective on the factors predicting recycling behavior: implications from the theory of planned behavior," Waste Management, vol. 62, pp. 290-302, 2017.

[34] M. Fishbein and I. Ajzen, Predicting and Changing Behavior: The Reasoned Action Approach, Psychology Press, NY, USA, 2010.

[35] N. T. Feather and J. W. Newton, "Values, expectations, and the prediction of social action: an expectancy-valence analysis," Motivation and Emotion, vol. 6, no. 3, pp. 217-244, 1982.

[36] R. B. Cialdini, R. R. Reno, and C. A. Kallgren, "A focus theory of normative conduct: recycling the concept of norms to reduce littering in public places," Journal of Personality and Social Psychology, vol. 58, no. 6, pp. 1015-1026, 1990.

[37] I. Moons and P. De Pelsmacker, "An extended decomposed theory of planned behaviour to predict the usage intention of the electric car: a multi-group comparison," Sustainability, vol. 7, no. 5, pp. 6212-6245, 2015.

[38] A. Nayum, C. A. Klöckner, and M. Mehmetoglu, "Comparison of socio-psychological characteristics of conventional and battery electric car buyers," Travel Behaviour and Society, vol. 3, pp. 8-20, 2016.

[39] A. Nayum, C. A. Klöckner, and S. Prugsamatz, "Influences of car type class and carbon dioxide emission levels on purchases of new cars: a retrospective analysis of car purchases in Norway," Transportation Research Part A: Policy and Practice, vol. 48, pp. 96-108, 2013. 
[40] R. N. Rimal and K. Real, "Understanding the influence of perceived norms on behaviors," Communication Theory, vol. 13, no. 2, pp. 184-203, 2003.

[41] K. M. White, J. R. Smith, D. J. Terry, J. H. Greenslade, and B. M. McKimmie, "Social influence in the theory of planned behaviour: the role of descriptive, injunctive, and in-group norms," British Journal of Social Psychology, vol. 48, no. 1, pp. 135-158, 2009.

[42] A. Khare, "Antecedents to green buying behaviour: a study on consumers in an emerging economy," Marketing Intelligence \& Planning, vol. 33, no. 3, pp. 309-329, 2015.

[43] N. L. Mosquera, F. L. López, and M. Sánchez, "Key factors to explain recycling, car use and environmentally responsible purchase behaviors: a comparative perspective," Resources, Conservation and Recycling, vol. 99, pp. 29-39, 2015.

[44] R. Nimri, A. Patiar, and X. Jin, "The determinants of consumers' intention of purchasing green hotel accommodation: e," Journal of Hospitality and Tourism Management, vol. 45, pp. 535-543, 2020.

[45] S.-J. Moon, "Investigating beliefs, attitudes, and intentions regarding green restaurant patronage: an application of the extended theory of planned behavior with moderating effects of gender and age," International Journal of Hospitality Management, vol. 92, Article ID 102727, 2021.

[46] P. C. Stern, T. Dietz, T. Abel, G. A. Guagnano, and L. Kalof, "A value-belief-norm theory of support for social movements: the case of environmentalism," Research in Human Ecology, vol. 6, no. 2, pp. 81-97, 1999.

[47] H. Han, "Travelers' pro-environmental behavior in a green lodging context: converging value-belief-norm theory and the theory of planned behavior," Tourism Management, vol. 47, pp. 164-177, 2015.

[48] S. Bamberg and P. Schmidt, "Incentives, morality, or habit? Predicting students' car use for university routes with the models of ajzen, schwartz, and triandis," Environment and Behavior, vol. 35, no. 2, pp. 264-285, 2003.

[49] F. Fornara, P. Pattitoni, M. Mura, and E. Strazzera, "Predicting intention to improve household energy efficiency: the role of value-belief-norm theory, normative and informational influence, and specific attitude," Journal of Environmental Psychology, vol. 45, pp. 1-10, 2016.

[50] M. G. Chung, H. Kang, T. Dietz, P. Jaimes, and J. Liu, "Activating values for encouraging pro-environmental behavior: the role of religious fundamentalism and willingness to sacrifice," Journal of Environmental Studies and Sciences, vol. 9, no. 4, pp. 371-385, 2019.

[51] P. C. Stern, T. Dietz, and L. Kalof, "Value orientations, gender, and environmental concern," Environment and Behavior, vol. 25, no. 5, pp. 322-348, 1993.

[52] J. I. M. D. Groot and L. Steg, "Value orientations to explain beliefs related to environmental significant behavior," Environment and Behavior, vol. 40, no. 3, pp. 330-354, 2008.

[53] L. Steg, J. I. M. De Groot, L. Dreijerink, W. Abrahamse, and F. Siero, "General antecedents of personal norms, policy acceptability, and intentions: the role of values, worldviews, and environmental concern," Society \& Natural Resources, vol. 24, no. 4, pp. 349-367, 2011.

[54] R. S. Snelgar, "Egoistic, altruistic, and biospheric environmental concerns: measurement and structure," Journal of Environmental Psychology, vol. 26, no. 2, pp. 87-99, 2006.

[55] K. B. Chua, F. Quoquab, J. Mohammad, and R. Basiruddin, "The mediating role of new ecological paradigm between value orientations and pro-environmental personal norm in the agricultural context," Asia Pacific Journal of Marketing \& Logistics, vol. 28, no. 2, pp. 323-349, 2016.

[56] T. N. Nguyen, A. Lobo, and S. Greenland, "The influence of Vietnamese consumers' altruistic values on their purchase of energy efficient appliances," Asia Pacific Journal of Marketing \& Logistics, vol. 29, no. 4, pp. 759-777, 2017.

[57] E. A. Obeng and F. X. Aguilar, "Value orientation and payment for ecosystem services: perceived detrimental consequences lead to willingness-to-pay for ecosystem services," Journal of Environmental Management, vol. 206, pp. $458-471,2018$.

[58] R. Rhead, M. Elliot, and P. Upham, "Assessing the structure of UK environmental concern and its association with proenvironmental behaviour," Journal of Environmental Psychology, vol. 43, pp. 175-183, 2015.

[59] J. L. Lau, A. H. Hashim, A. A. Samah, and A. S. S. Salim, "Understanding the environmental worldviews of Malaysian project managers," Smart and Sustainable Built Environment, vol. 5, no. 4, pp. 307-324, 2016.

[60] T. Perrea, A. Krystallis, Y. Zhou, G. Huang, and Y. Hue, "Testing and validation of a hierarchical values-attitudes model in the context of green food in China," Asia Pacific Journal of Marketing \& Logistics, vol. 26, no. 2, pp. 296-314, 2014.

[61] H. Han, J. Hwang, J. Kim, and H. Jung, "Guests' pro-environmental decision-making process: b," International Journal of Hospitality Management, vol. 47, pp. 96-107, 2015.

[62] P. Forum, The Global Religious Landscape, http://www. pewforum.org/2012/12/18/global-religious-landscape-exec/, 2012.

[63] A. D. Guritno, E. Schlich, E. Pawelzik, and D. Ismoyowati, "International conference on agro-industry (IcoA): sustainable and competitive agro-industry for human welfare yogyakartaIndonesia 2014Halal food marketing: a case study on consumer behavior of chicken-based processed food consumption in central part of java, Indonesia," Agriculture and Agricultural Science Procedia, vol. 3, pp. 169-172, 2015.

[64] M. G. Mohayidin and N. H. Kamarulzaman, "Consumers' preferences toward attributes of ManufacturedHalalFood products," Journal of International Food \& Agribusiness Marketing, vol. 26, no. 2, pp. 125-139, 2014.

[65] W. E. Wan Rashid, M. Muda, M. W. Wibowo, and F. S. Ahmad, "The fifth international conference on marketing and retailing (5th INCOMaR) 2015Non-muslim consumers' halal food product acceptance model," Procedia Economics and Finance, vol. 37, pp. 276-283, 2016.

[66] J. Fischer, "Markets, religion, regulation: kosher, halal and Hindu vegetarianism in global perspective," Geoforum, vol. 69, pp. 67-70, 2016.

[67] D. Ismoyowati, "Halal food marketing: a case study on consumer behavior of chicken-based processed food consumption in central part of java, Indonesia," Agriculture and Agricultural Science Procedia, vol. 3, pp. 169-172, 2015.

[68] A. A. Khalek, "Young consumers' attitude towards halal food outlets and JAKIM's halal certification in Malaysia," Procedia - Social and Behavioral Sciences, vol. 121, pp. 26-34, 2014.

[69] M. Said, F. Hassan, R. Musa, and N. A. Rahman, “Assessing consumers' perception, knowledge and religiosity on Malaysia's halal food products," Procedia - Social and Behavioral Sciences, vol. 130, pp. 120-128, 2014.

[70] W. Verbeke, P. Rutsaert, K. Bonne, and I. Vermeir, "Credence quality coordination and consumers' willingness-topay for certified halal labelled meat," Meat Science, vol. 95, no. 4, pp. 790-797, 2013. 
[71] R. Felix and K. Braunsberger, "I believe therefore I care," International Marketing Review, vol. 33, no. 1, pp. 137-155, 2016.

[72] S. Pace, "Does religion affect the materialism of consumers? An empirical investigation of buddhist Ethics and the resistance of the self," Journal of Business Ethics, vol. 112, no. 1, pp. 25-46, 2013.

[73] A. L. B. Hope and C. R. Jones, "The impact of religious faith on attitudes to environmental issues and Carbon Capture and Storage (CCS) technologies: a mixed methods study," Technology in Society, vol. 38, pp. 48-59, 2014.

[74] I. Abdul-Matin, Green Deen - what Islam Teaches about Protecting the Planet, Berrett-Koehler Publishers, Inc, San Fransisco, CA, USA, 2010.

[75] M. Fishbein and I. Ajzen, Predicting and Changing Behavior: The Reasoned Action Approach, Taylor \& Francis, NY, USA, 2011.

[76] P. C. Stern, "New environmental theories: toward a coherent theory of environmentally significant behavior," Journal of Social Issues, vol. 56, no. 3, pp. 407-424, 2000.

[77] J. Hiratsuka, G. Perlaviciute, and L. Steg, "Testing VBN theory in Japan: relationships between values, beliefs, norms, and acceptability and expected effects of a car pricing policy," Transportation Research Part F: Traffic Psychology and Behaviour, vol. 53, pp. 74-83, 2018.

[78] L. Steg, L. Dreijerink, and W. Abrahamse, "Factors influencing the acceptability of energy policies: a test of VBN theory," Journal of Environmental Psychology, vol. 25, no. 4, pp. 415-425, 2005.

[79] Central Intelligence Agency, "The world factbook-pakistan," 2020, https://www.cia.gov/library/publications/the-worldfactbook/geos/pk.html.

[80] Pakistan Bureau of Statistics, "Block wise provisional summary results of 6th population \& housing census-2017," 2018, http://www.pbscensus.gov.pk/.

[81] F. Ali, S. M. Rasoolimanesh, M. Sarstedt, C. M. Ringle, and K. Ryu, "An assessment of the use of partial least squares structural equation modeling (PLS-SEM) in hospitality research," International Journal of Contemporary Hospitality Management, vol. 30, no. 1, pp. 514-538, 2018.

[82] J. F. Hair, M. Sarstedt, C. M. Ringle, and S. P. Gudergan, Advanced Issues in Partial Least Squares Structural Equation Modeling, SAGE Publications, CA, USA, 2017.

[83] D. C. Giles, Advanced Research Methods in Psychology, Routledge, NY, USA, 2002.

[84] A. Field, Discovering Statistics Using IBM SPSS Statistics, SAGE Publications, CA, USA, North American edition, 2017.

[85] P. M. Podsakoff, S. B. MacKenzie, J.-Y. Lee, and N. P. Podsakoff, "Common method biases in behavioral research: a critical review of the literature and recommended remedies," Journal of Applied Psychology, vol. 88, no. 5, pp. 879-903, 2003.

[86] A. B. Costello and J. W. Osborne, "Best practices in exploratory factor Analysis: four recommendations for getting the most from your analysis," Practical Assessment, Research and Evaluation, vol. 10, no. 7, pp. 1-9, 2005.

[87] H. F. Kaiser, "An index of factorial simplicity," Psychometrika, vol. 39, no. 1, pp. 31-36, 1974.

[88] J. F. Hair, Multivariate Data Analysis, Prentice-Hall, NJ, USA, 2010.

[89] A. C. Burns, A. Veeck, and R. F. Bush, Marketing Research, PEARSON EDUC, London, UK, 2016.
[90] C. J. Nunnally, Psychometric Theory, McGraw-Hill, NY, USA, 1978.

[91] C. Fornell and D. F. Larcker, "Evaluating structural equation models with unobservable variables and measurement error," Journal of Marketing Research, vol. 18, no. 1, pp. 39-50, 1981.

[92] J. Henseler, C. M. Ringle, and M. Sarstedt, "A new criterion for assessing discriminant validity in variance-based structural equation modeling," Journal of the Academy of Marketing Science, vol. 43, no. 1, pp. 115-135, 2015.

[93] J. Cohen, Statistical Power Analysis for the Behavioral Sciences, Taylor \& Francis, Oxfordshine, United Kingdom, 2013.

[94] W. W. Chin, "How to write up and report PLS analyses," in Handbook of Partial Least Squares: Concepts, Methods and Applications, V. Esposito Vinzi, W. W. Chin, J. Henseler, and H. Wang, Eds., Springer, Berlin, Heidelberg, Germany, pp. 655-690, 2010.

[95] J. F. Hair, C. B. Astrachan, O. I. Moisescu et al., "Executing and interpreting applications of PLS-SEM: updates for family business researchers," Journal of Family Business Strategy, vol. 12, no. 3, Article ID 100392, 2020.

[96] G. Shmueli, S. Ray, J. M. E. Velasquez, and S. B. Chatla, “The elephant in the room: predictive performance of PLS models," Journal of Business Research, vol. 69, no. 10, pp. 4552-4564, 2016.

[97] S. Bhuian and S. K. Sharma, "Predicting consumer proenvironmental behavioral intention," Review of International Business and Strategy, vol. 27, no. 3, pp. 352-368, 2017.

[98] T. Islam, U. Chandrasekaran, and U. Chandrasekaran, "Religiosity and ecologically conscious consumption behaviour," Asian Journal of Business Research, vol. 5, no. 2, 2015.

[99] Y. Yang and S. Huan, "Religious beliefs and environmental behaviors in China," Religions, vol. 9, no. 3, pp. 1-12, 2018.

[100] K. K. Chen, "Assessing the effects of customer innovativeness, environmental value and ecological lifestyles on residential solar power systems install intention," Energy Policy, vol. 67, pp. 951-961, 2014.

[101] E. Fraj and E. Martinez, "Environmental values and lifestyles as determining factors of ecological consumer behaviour: an empirical analysis," Journal of Consumer Marketing, vol. 23, no. 3, pp. 133-144, 2006.

[102] J. Jansson, A. Marell, and A. Nordlund, "Exploring consumer adoption of a high involvement eco-innovation using valuebelief-norm theory," Journal of Consumer Behaviour, vol. 10, no. 1, pp. 51-60, 2011.

[103] C. Dewberry and D. J. R. Jackson, "An application of the theory of planned behavior to student retention," Journal of Vocational Behavior, vol. 107, pp. 100-110, 2018.

[104] O. I. Macovei, "Applying the theory of planned behavior in predicting proenvironmental behaviour: the case of energy conservation," Acta Universitatis Danubius. OEconomica, vol. 11, no. 4, pp. 15-32, 2015.

[105] K. Maichum, S. Parichatnon, and K. C. Peng, "Application of the extended theory of planned behavior model to investigate purchase intention of green products among Thai consumers," Sustainability, vol. 8, no. 10, pp. 1-20, 2016.

[106] A. Morten, B. Gatersleben, and D. C. Jessop, "Staying grounded? Applying the theory of planned behaviour to explore motivations to reduce air travel," Transportation Research Part F: Traffic Psychology and Behaviour, vol. 55, pp. 297-305, 2018.

[107] M. A. Saleem, Model of Eco-Socially Conscious Consumer Behaviour Related to Choice and Use of Personal Cars: Evidence from an Emerging Economy, James Cook University, Townsville, Australia, 2019. 